\title{
Glucosaminidase of Bacillus subtilis: cloning, regulation, primary structure and biochemical characterization
}

\author{
Muhammad H. Rashid, Masao Mori and Junichi Sekiguchi
}

Author for correspondence: Junichi Sekiguchi. Tel: +81268 22 1215. Fax: +81268224079. e-mail: jsekigu@giptc.shinshu-u.ac.jp

Department of Applied Biology, Faculty of Textile Science \& Technology, Shinshu University, 3-15-1 Tokida, Ueda-shi, Nagano 386, Japan
The $90 \mathrm{kDa}$ glucosaminidase protein was purified to apparent homogeneity from vegetative cells of Bacillus subtilis AC327, and then the corresponding gene was cloned into Escherichia coli in two inactive forms by standard procedures. Nucleotide sequencing of the glucosaminidase region revealed a monocistronic operon, (designated lytD = cw/G) encoding a 95.6 kDa protein, comprising $\mathbf{8 8 0}$ amino acid residues, which has a typical signal peptide. Moreover, another monocistronic operon (designated $\mathbf{p m i}=$ orfX), encoding a 35.4 kDa protein, was found upstream of the glucosaminidase gene. Expression of a lytD-lacz fusion gene, driven by lytD regulatory sequences, was observed during the exponential growth phase. The introduction of a sigD null mutation greatly reduced (by about $95 \%$ ) the expression of the fusion. Amino acid sequence analysis of the glucosaminidase showed two types of direct repeats, each type being present twice, in the $\mathrm{N}$-terminal-to-central region of the glucosaminidase: these repeats probably represent the cell-wall-binding domain. Zymographic analysis revealed that the $90 \mathrm{kDa}$ glucosaminidase is partly processed to several smaller proteins (35-39 kDa), retaining lytic activity. Processing of these proteins occurred between the $\mathbf{N}$-terminal cellwall-binding and C-terminal catalytic domains of the glucosaminidase, the site being located between the 569th and 606th codons of the glucosaminidase. Serial deletions from the N-terminus of the glucosaminidase revealed that the loss of more than one repeating unit drastically reduces its lytic activity toward cell walls. The lytD gene product, in either an intact or a truncated form, was found to be lethal for $E$. coll, and the N-terminally truncated glucosaminidase proteins, produced in $E$. coli, were very unstable. The partially purified glucosaminidase from $B$. subtilis was found to be very unstable at low ionic strength at $37^{\circ} \mathrm{C}$, but this instability was overcome by the addition of either SDS-purified cell wall or protease inhibitor (PMSF) to the enzyme or after purification of the glucosaminidase to apparent homogeneity.

Keywords: Bacillus subtilis, autolysin, endo- $\beta$ - $N$-acetylglucosaminidase, $\sigma^{\mathrm{D}}$, protein domain

\section{INTRODUCTION}

The rod-shaped, Gram-positive soil bacterium, Bacillus subtilis, produces a complement of enzymes capable of dissolving the shape-maintaining and stress-bearing

Abbreviations : CBB, Coomassie Brilliant Blue; S/FMP, slow/fast-migrating protein.

The GSDB/DDBJ/EMBL/NCBI accession number for the nucleotide sequence reported in this paper is D45048. peptidoglycan layer of its own cell wall (Rogers et al., 1980; Doyle \& Koch, 1987; Shockman \& Höltje, 1994). Some of these peptidoglycan hydrolases can trigger cell lysis: therefore, they can truly be called 'autolysins' or 'suicide enzymes' (Rogers et al., 1980). Autolysins have been implicated in several important cellular processes, such as cell wall turnover, cell separation, competence and flagellation (motility), in addition to cell lysis, and they act as pacemaker and spacemaker enzymes for cell wall growth (Rogers et al., 1980; Fein \& Rogers, 1976; Fein, 
1979; Ayusawa et al., 1975; Pooley \& Karamata, 1984). Therefore, fine tuning of autolysin activity through efficient and strict regulation is a must for bacterial survival (Höltje \& Tuomanen, 1991).

Two major vegetative-phase autolysins [a $50 \mathrm{kDa}$ $N$-acetylmuramoyl-L-alanine amidase (amidase) and a $90 \mathrm{kDa}$ endo- $\beta$ - $N$-acetylglucosaminidase (glucosaminidase)] were initially purified and characterized from B. subtilis (Herbold \& Glaser, 1975; Rogers et al., 1984). Recently, the gene encoding the $50 \mathrm{kDa}$ amidase $(\mathrm{CwlB}=\mathrm{LytC})$ was cloned and studied at the molecular level (Kuroda \& Sekiguchi, 1991; Lazarevic et al., 1992). The $c w l B(l y t C)$ gene is part of an operon encoding a putative lipoprotein (lyt $A=l p p X)$, a modifier protein $(l y t B=c w b A)$, and the $c w l B$ gene, in that order (Kuroda $e t$ al., 1992a; Kuroda \& Sekiguchi, 1993). Transcription of this operon proceeds from a distal $\sigma^{\mathrm{A}}$-type and a proximal $\sigma^{\mathrm{D}}$-type promoter, the latter transcripts being predominant in the exponential growth phase (Kuroda \& Sekiguchi, 1993). At least two pleiotropic mutations, $\operatorname{faD}(=\sin )$ and $\operatorname{deg} S-\operatorname{deg} U$, affect the transcription of the cw/B operon (Kuroda \& Sekiguchi, 1993; Tokunaga et al., 1994). Previously, we reported the cloning of a part of the glucosaminidase gene, lyt $D(=c w l G)$, its inactivation on the chromosome, and the construction of a CwlB- and LytD-deficient strain (Rashid et al., 1993). A search for the physiological functions of CwlB and LytD revealed that $\mathrm{CwlB}$ is responsible for cell lysis at the stationary phase (Kuroda \& Sekiguchi, 1991) and that both proteins, but only in concert, are required for the motility function (Rashid et al., 1993).

Several other amidase genes have been cloned from the genus Bacillus. From $B$. subtilis, two prophage-encoded amidase genes ( $c w l A$ and $x l y A$ ) (Kuroda \& Sekiguchi, 1990; Foster, 1991; Longchamp et al., 1994), and a sporulation-specific amidase gene $(\mathrm{cw} / \mathrm{C}$ ) (Kuroda et al., 1993) have been cloned, in addition to $c w / B$. From $B$. licheniformis, two amidase genes ( $c w l M$ and $c w l L)$, and from Bacillus sp., a cell-wall hydrolase (probably an amidase) gene have also been cloned and studied (Kuroda et al., 1992b; Oda et al., 1993; Potvin et al., 1988). Evidence has accumulated that these amidases are composed of a cell-wall-binding domain and a catalytic domain (Kuroda et al., 1992b). On the basis of the amino acid sequence similarity in their catalytic domains, these amidases can be classified into two groups. Class I includes CwlA, CwlL, XlyA and Bacillus sp. amidase, and class II includes $\mathrm{CwlB}, \mathrm{CwlC}$ and $\mathrm{CwlM}$. The cell-wall-binding domains of these amidases contain several (usually two or three) tandemly repeated sequences. Interestingly, three tandemly repeated sequences have also been observed in the non-catalytic cell-wall-binding proteins, $\mathrm{LytB}$ and WapA (Kuroda et al., 1992a; Foster, 1992). However, until now, the primary structure of the glucosaminidase has remained unexplored. To further our understanding of the regulation and primary structure of the glucosaminidase, we report here the nucleotide sequence, transcriptional regulation, protein structure and biochemical characterization of the major glucosaminidase of
B. subtilis. In addition, we present the nucleotide sequence of the adjacent upstream monocistronic operon.

Recently, Margot et al. (1994) independently reported the cloning and nucleotide sequence of the glucosaminidase gene (glucosaminidase and adjacent upstream genes designated as lytD and $p m i$, respectively), using an entirely different approach. For consistency and ease of comparison with these data, we use the nomenclature $l y t D$, and not $c w / G$ (Rashid et al., 1993) in this paper.

\section{METHODS}

Bacterial strains, plasmids and phage. The strains, plasmids and phage used in this study are listed in Table 1. Plasmid pMW118 is a low-copy vector (five copies per cell) for $E$. coli, and plasmid pHY300PLK is a shuttle vector for E. coli and $B$. subtilis (Takara). Plasmid pDEB1 is a transcriptional lac $Z$ fusion vector (Schreier \& Sonenshein, 1986).

Media and culture conditions. B. subtilis strains were grown in either bacto-peptone (BP) medium (Rashid et al., 1993) or Schaeffer's sporulation medium (Schaeffer et al., 1965) at $28^{\circ} \mathrm{C}$ with shaking. E. coli was grown in LB medium at $37^{\circ} \mathrm{C}$. If necessary, ampicillin (Ap) and/or chloramphenicol $(\mathrm{Cm})$ were added to final concentrations of 100 and $5 \mu \mathrm{g} \mathrm{ml}^{-1}$, respectively. Tetracycline (Tc) was added to a final concentration of $20 \mu \mathrm{g}$ $\mathrm{ml}^{-1}$ for the selection of multicopy plasmids and $8 \mu \mathrm{g} \mathrm{ml}^{-1}$ for the selection of a single chromosomal copy.

Purification of the glucosaminidase. B. subtilis AC327 was cultured in $1101 \mathrm{BP}$ medium (Rashid et al., 1993), in a 2001 fermenter, at $28^{\circ} \mathrm{C}$ to $\mathrm{OD}_{660} 2 \cdot 5$ (UV-1200, Shimadzu). The culture was then rapidly cooled to $4{ }^{\circ} \mathrm{C}$ and the cells, after centrifugation at $10000 \mathrm{~g}$ for $5 \mathrm{~min}$, were stored at $-80^{\circ} \mathrm{C}$. About $300 \mathrm{~g}$ wet weight (equivalent to $50 \mathrm{l}$ culture) frozen cells was melted on ice and then washed with $500 \mathrm{ml}$ buffer $T$ solution $(25 \mathrm{mM}$ Tris/ $\mathrm{HCl}, \mathrm{pH} \mathrm{7 \cdot 2)}$. The cells were suspended in $500 \mathrm{ml} 5 \mathrm{M} \mathrm{LiCl} /$ buffer $\mathrm{T}$ solution and then incubated at $0^{\circ} \mathrm{C}$ for $60 \mathrm{~min}$. The supernatant $(500 \mathrm{ml})$, obtained by centrifugation at $27000 \mathrm{~g}$ for $10 \mathrm{~min}$, was used as a crude extract (extract A). Extract A was then diluted 10-fold with buffer $\mathrm{T}$, followed by the addition of $M$. luteus cell wall $(2 \cdot 0 \mathrm{~g})$ treated with SDS, and then the mixture was incubated with slow stirring at $0{ }^{\circ} \mathrm{C}$ for $30 \mathrm{~min}$. After washing with a $0.5 \mathrm{M} \mathrm{LiCl} /$ buffer $\mathrm{T}$ solution, the cell wall pellet was extracted with $100 \mathrm{ml} 5 \mathrm{M}$ $\mathrm{LiCl} /$ buffer $\mathrm{T}$ solution at $0{ }^{\circ} \mathrm{C}$ for $30 \mathrm{~min}$. The supernatant $(100 \mathrm{ml})$ was used as a cell wall extract (extract B). Extract B was then concentrated by ultrafiltration to approximately $7 \cdot 0 \mathrm{ml}$. The concentrated extract (extract $\mathrm{C}$ ) was applied to a column $(2.0 \times 150 \mathrm{~cm})$ of Toyopearl HW-55 Superfine ('Tosoh) equilibrated with $2 \mathrm{M} \mathrm{LiCl} /$ buffer $\mathrm{T}$. The column was eluted with the same buffer. Fractions containing cell-wall-lytic activity were pooled and used as the purified enzyme sample (HW-55 fraction).

Preparation of cell walls and assaying cell-wall-lytic activity. Cell walls of $B$. subtilis 168 S and M. luteus ATCC4698 were prepared essentially as described previously (Fein \& Rogers, 1976; Kuroda \& Sekiguchi, 1990). Lytic activity was measured as described by Rogers et al. (1984). The reaction mixture $(5 \mathrm{ml}$ ), consisting of $M$. luteus cell wall (to a final $\mathrm{OD}_{540} 0.3$ ) in a $50 \mathrm{mM}$ sodium succinate $/ \mathrm{HCl}(\mathrm{pH} 5.5)$ buffer and the enzyme extract, was incubated with slow shaking at $37^{\circ} \mathrm{C}$. The final salt concentration of the reaction mixture was maintained at $0.25 \mathrm{M}$ $\mathrm{LiCl}$. One unit $(\mathrm{U})$ of enzyme activity was defined as the amount of the enzyme necessary to decrease $\mathrm{OD}_{\mathbf{5 4 0}}$ by 0.001 in $1 \mathrm{~min}$.

Determination of reducing sugar. The release of free reducing groups during the enzymic reaction was assayed by the 
Table 1. Bacterial strains, phage and plasmids

\begin{tabular}{|c|c|c|}
\hline & Genotype/phenotype & Source/reference \\
\hline \multicolumn{3}{|l|}{ B. subtilis } \\
\hline 168 & $\operatorname{trp} C 2$ & This laboratory \\
\hline $168 \mathrm{~S}$ & $\operatorname{trp} C 2 \operatorname{str} A$ smo-1 & $\begin{array}{l}\text { Sekiguchi et al. } \\
\text { (1988) }\end{array}$ \\
\hline AC327 & purB bis-1 smo-1 & $\begin{array}{l}\text { Sekiguchi et al. } \\
\text { (1988) }\end{array}$ \\
\hline AG1 & $\begin{array}{l}\text { purB bis-1 smo-1 } \\
\text { lytD::cat }\end{array}$ & Rashid et al. (1993) \\
\hline AN8 & $\begin{array}{l}\text { purB bis-1 smo-1 } \\
\text { cwlB:: cat }\end{array}$ & $\begin{array}{l}\text { Kuroda \& } \\
\text { Sekiguchi (1991) }\end{array}$ \\
\hline AGB1 & $\begin{array}{l}\text { purB bis-1 smo-1 } \\
\text { lytD::cat cwlB:: tet }\end{array}$ & Rashid et al. (1993) \\
\hline $168 \mathrm{G} 1$ & $\operatorname{trp} C 2$ lytD::cat & This study \\
\hline $168 \mathrm{~N} 8$ & $\operatorname{trp} C 2 c w l B:: c a t$ & This study \\
\hline 168GB1 & $\begin{array}{l}\operatorname{trp} C 2 \text { lytD: : cat } \\
\text { cwlB:: tet }\end{array}$ & This study \\
\hline $1 \mathrm{~A} 680$ & $\operatorname{trp} C 2 \operatorname{lac} A 17$ lacR 1 & $\begin{array}{l}\text { Errington \& Vogt } \\
(1990) ; \text { BGSC* }\end{array}$ \\
\hline 680GL20 & $\begin{array}{l}\operatorname{trp} C 2 \text { lac } A 17 \text { lacR1 } \\
\text { lytD-lacZ } \mathrm{Cm}^{\mathrm{r}}\end{array}$ & This study \\
\hline 680GL22 & $\begin{array}{l}\operatorname{trpC} 2 \text { lac } A 17 \text { lacR } 1 \\
\text { lytD-lacZ Cm } \\
\text { sigD:: tet }\end{array}$ & This study \\
\hline \multicolumn{3}{|l|}{ M. luteus } \\
\hline ATCC4698 & & Sigma \\
\hline \multicolumn{3}{|l|}{ E. coli } \\
\hline JM109 & $\begin{array}{l}\operatorname{rec} A 1 \Delta(\text { lac-pro } A B) \\
\text { end } A 1 \text { gyr } A 96 \text { thi1 } \\
\text { bsdR17 relA1 supE44 } \\
{\left[\mathrm{F}^{\prime}: \text { traD36 pro } A B\right.} \\
\left.\text { lacI } I^{\mathrm{G}} \mathrm{ZM} 15\right]\end{array}$ & Takara \\
\hline JM103 & $\begin{array}{l}\text { supE sbcB15 bsdR4 rpsL } \\
\text { thi } \Delta(\text { lac-pro } A B) \\
{\left[\mathrm{F}^{\prime}: \text { traD } 36 \text { pro } A B\right.} \\
\left.\text { lac }{ }^{\mathrm{T}} \mathrm{Z} \Delta \mathrm{M} 15\right]\end{array}$ & Takara \\
\hline \multicolumn{3}{|l|}{ Phage } \\
\hline $\mathrm{M} 13 \mathrm{mp} 18$ & & Takara \\
\hline \multicolumn{3}{|l|}{ Plasmid } \\
\hline pUC118/119 & $\mathrm{Ap}^{\mathrm{r}} \mathrm{Lac}^{+}$ & Takara \\
\hline pMW118 & $\mathrm{Ap}^{\mathrm{r}} \mathrm{Lac}^{+}$ & Takara \\
\hline pHY300PLK & $A p^{r} T c^{r}$ & Takara \\
\hline $\mathrm{pEH} 4$ & $\mathrm{Ap}^{\mathrm{r}} 3^{\prime}$ lytD & Rashid et al. (1993) \\
\hline pWCEV4 & $A p^{r} 5^{\prime} l y t D \ddagger$ & This study \\
\hline pHYG & $\mathrm{Ap}^{\mathrm{r}} \mathrm{Tc}^{\mathrm{r}}$ lytD & This study \\
\hline pHYEB & $A p^{r} T c^{r} t l y t D S$ & This study \\
\hline pDEB1 & $\mathrm{Ap}^{\mathrm{r}} \mathrm{Cm}^{\mathrm{r}}$ & $\begin{array}{l}\text { Schreier \& Sonen- } \\
\text { shein (1986); BGSC }\end{array}$ \\
\hline pDEB1G & $A p^{\mathrm{r}} \mathrm{Cm}^{\mathrm{r}}$ lytD-lacZ & This study \\
\hline pUCTC & $A p^{r} T c^{r}$ & Rashid et al. (1993) \\
\hline pSD & $\mathrm{Ap}^{\mathrm{r}} \operatorname{sig} D$ & This study \\
\hline pSDTC & $\mathrm{Ap}^{\mathrm{r}}$ sigD::tet & This study \\
\hline
\end{tabular}

* Bacillus Genetic Stock Center, Ohio State University.

$+5^{\prime}$-Terminal 440 bp of the lytD gene are deleted.

$\ddagger 3^{\prime}$-Terminal 424 bp of the $l y t D$ gene are deleted.

\C-Terminal 187 amino acids of LytD are replaced by 19 alien amino acids.
Thompson \& Shockman (1968) modification of the method of Park \& Johnson using $N$-acetylglucosamine as the standard.

Cloning of the 5'-terminal-to-upstream region of the glucosaminidase gene. Southern hybridization analysis (Sambrook $e t$ al., 1989) of B. subtilis AC327 chromosomal DNA with the $\alpha-{ }^{32}$ P-labelled $0.4 \mathrm{~kb}$ Pst I segment as a probe, which is internal to the glucosaminidase gene (Rashid et al., 1993), indicated that a $4.0 \mathrm{~kb}$ ClaI-EcoRV DNA segment contains the $5^{\prime}$-terminalto-upstream region of the glucosaminidase gene. Thus, ClaI/EcoRV-digested fragments of B. subtilis AC327 chromosomal DNA were separated by agarose gel electrophoresis, and 3.5 to $4.5 \mathrm{~kb}$ fragments were purified with a Gene-Clean kit II (Bio 101). The DNA fragments were then ligated into the AccI-SmaI site of pMW118. After transformation of E. coli JM109 with the ligated DNA, Ap ${ }^{r}$ colonies were selected and colony hybridized (Sambrook et al., 1989) with the $\alpha^{32} \mathrm{P}$ labelled $0.4 \mathrm{~kb}$ PstI fragment of pEH4 (Rashid et al., 1993) as a probe. Nine positive clones were isolated from $300 \mathrm{Ap}^{\mathrm{r}}$ colonies harbouring an identical plasmid, pWCEV4 (plasmid pMW118 containing a $4 \cdot 1 \mathrm{~kb}$ insert).

Construction of PEH4- and PWCEV4-derivatives for sequencing. $\mathrm{pEH} 4$-derivatives $\mathrm{pEVH}, \mathrm{pBP}, \mathrm{pHHII}, \mathrm{pBB}$, pHIIP, pPP, $\mathrm{pPH}$ and $\mathrm{pHII}$ were constructed by subcloning $2.4 \mathrm{~kb}$ EcoRV-HindIII, $1.8 \mathrm{~kb}$ BamHI-PstI, $1.2 \mathrm{~kb}$ HindIIIHincII, $0.8 \mathrm{~kb}$ Bam HI, 0.54 kb HincII-PstI, $0.4 \mathrm{~kb}$ Pst $\mathrm{I}, 0.23 \mathrm{~kb}$ Pst I-HindIII and $0.33 \mathrm{~kb}$ HincII fragments from $\mathrm{pEH} 4$ (Rashid et al., 1993) into the respective sites of pUC118 (Fig. 2). pWCEV4 derivatives pCCS and pWSEV were obtained by subcloning the $2.3 \mathrm{~kb} S p h \mathrm{I}$ fragment of pWCEV4 into the $S p h \mathrm{I}$ site of pUC118, and by self-circularization of the vector fragment upon SphI digestion, respectively. PCPS was obtained by self-circularization of the pCCS vector fragment upon Pst I digestion, and $\mathrm{pCSH}$ was a pUC118-derivative containing the $1.2 \mathrm{~kb}$ HindIII fragment of $\mathrm{pWSEV}$. To construct plasmid derivatives for sequencing of the $1.2 \mathrm{~kb} H$ indIII-SpbI fragment of pWCEV4 (Fig. 2), the random subcloning approach was taken. The $1.2 \mathrm{~kb}$ HindIII fragment of $\mathrm{pWSEV}$ was digested with Sau3AI or MspI, followed by ligation with BamHI- or AccI-digested and de-phosphorylated pUC118, respectively. After transformation of E. coli, colonies were randomly chosen as sequencing templates.

DNA sequencing. Nucleotide sequencing was performed with double-stranded plasmid DNA as templates, using M13 universal (M4) and reverse (RV) primers (Takara). Sequencing was performed with an Applied Biosystems 373A DNA Sequencer using a Taq Dye-Deoxy Terminator Cycle Sequencing kit. To fill in the gap or to determine the opposite strand sequence (where needed), oligonucleotide primers were synthesized with an Applied Biosystems 391S DNA synthesizer. The sequences of both strands were determined for the $4.2 \mathrm{~kb}$ HindIII-EcoRV fragment, and partially for the $\operatorname{tag} A B C$ and ger $B$ regions.

Construction of a /ytD-lacz fusion strain and introduction of a sigD null mutation in the /ytD-lacZ background. pWCEV4 was digested with HincII and HindIII and the $1.7 \mathrm{~kb}$ HindIII fragment was subcloned into pUC118, resulting in plasmid pUC1.7 (Fig. 2). The $1.7 \mathrm{~kb}$ HindIII fragment of pUC1.7, containing the $5^{\prime}$-terminus and upstream regulatory sequences of the glucosaminidase gene, was then inserted into the unique HindIII site of plasmid pDEB1 (Schreier \& Sonenshein, 1986). The orientation of the insert in one of the resultant plasmids, pDEB1G, was determined from the distance between the unique PstI site of the vector and the unique $S p h I$ site of the insert. Competent cells of B. subtilis 1 A680 (Errington \& Vogt, 1990) 
were transformed with the integrative plasmid, pDEB1G, and $\mathrm{Cm}^{\mathrm{r}}$ transformants were selected. One of the $\mathrm{Cm}^{\mathrm{r}}$ transformants was designated $B$. subtilis 680GL20.

Plasmid pSD is a pUC119-derivative containing the entire sigD gene and was constructed as follows. A $0.59 \mathrm{~kb} \mathrm{SalI-EcoRI}$ fragment containing the 5 'terminus of sigD from $\mathrm{pJH6}-2$ (Helmann et al., 1988) and a $0.91 \mathrm{~kb}$ EcoRI-PstI fragment containing the 3 -terminus of sigD from pLM3 (Màrquez et al., 1990) were inserted into the PstI-SalI site of pUC119 by triple ligation. A $1.5 \mathrm{~kb}$ EcoRI-HindIII DNA fragment containing a $\mathrm{Tc}^{\mathrm{r}}$ gene, tet, from pUCTC (Rashid et al., 1993) was blunt-ended with the Klenow fragment and then inserted into the Klenowtreated unique Eco T14I site of pSD, resulting in plasmid pSDTC in which the sigD gene is disrupted at the 59th codon. Plasmid pSDTC was digested with AvaI and $A c c \mathrm{I}$ and the $3.0 \mathrm{~kb} A c c \mathrm{I}$ fragment containing the sigD:: tet gene cluster was purified with Gene-Clean. B. subtilis 680 GL20 was transformed with the purified DNA, followed by selection for $\mathrm{Tc}^{r}$. One $\mathrm{Tc}^{\mathrm{r}}$ transformant was designated $B$. subtilis $680 \mathrm{GL} 22$. The integration was confirmed by the filamentation and non-motility of the growing cells of strain 680GL22 (Màrquez et al., 1990).

$\boldsymbol{\beta}$-Galactosidase assay. The $\beta$-galactosidase assay was performed as described by Shimotsu \& Henner (1986). B. subtilis cells were centrifuged for $5 \mathrm{~min}$ in a microcentrifuge and then stored at $-80^{\circ} \mathrm{C}$. The frozen cells were suspended in $1 \mathrm{ml} \mathrm{Z}$ buffer (Miller, 1972) containing $300 \mu \mathrm{g}$ lysozyme $\mathrm{ml}^{-1}$ and $0.01 \%(\mathrm{v} / \mathrm{v})$ Triton $\mathrm{X}-100$, and then incubated at $37^{\circ} \mathrm{C}$ for $5 \mathrm{~min}$ after brief $(5 \mathrm{~s})$ vortexing. Samples were assayed for $\beta$ galactosidase activity by the method of Miller (1972).

Expression of the glucosaminidase and a truncated form of the glucosaminidase (tlytD/G10) in B. subtilis AG1. The $3.9 \mathrm{~kb}$ EcoRI (multicloning site, mcs)-Bam HI fragment of pWCEV4 (Fig. 2), containing the $p m i(\operatorname{orf} X)$ and tlytD (C-terminally deleted for 187 codons) genes was cloned into the respective sites of pHY300PLK, resulting in plasmid pHYEB. After amplification in E. coli, pHYEB was introduced into B. subtilis AG1 by the conventional method (Anagnostopoulos \& Spizizen, 1961). To construct a plasmid, pHYG, which expresses the intact glucosaminidase, the $0.8 \mathrm{~kb} \mathrm{BamHI}$ fragment of pEH4 (Fig. 2) was ligated with BamHI-cut and dephosphorylated pHYEB. B. subtilis AG1 was transformed with the ligated solution directly by the protoplast transformation method (Akamatsu \& Sekiguchi, 1987a, b). Proper orientation of the insert in pHYG was confirmed by the sizes of the AccI and $A c c$ III fragments.

B. subtilis AG1 harbouring $\mathrm{pHY} 300 \mathrm{PLK}$, $\mathrm{pHYEB}$ or $\mathrm{pHYG}$ was cultured in $200 \mathrm{ml} \mathrm{BP}$ medium with $20 \mu \mathrm{g}$ tetracycline $\mathrm{ml}^{-1}$ at $28{ }^{\circ} \mathrm{C}$ for $12 \mathrm{~h}$. After harvesting the cells by centrifugation, protein samples (extracts A and B) were prepared as previously described (Rashid et al., 1993).

Construction of plasmids producing $\mathbf{N}$-terminally truncated glucosaminidases in $\boldsymbol{E}$. coli. The basic strategy used to construct truncated glucosaminidase-producing plasmids was to fuse inframe restricted and modified (if necessary) DNA fragments containing truncated glucosaminidase genes into the multicloning sites of pUC vectors. Thus, synthesis of the modified glucosaminidases uses the promoter, RBS and initiation codon of the E. coli lac $Z$ gene, with the addition of several alien amino acids to their N-termini, and are inducible with IPTG.

A DNA fragment containing the $5^{\prime}$-terminus of the glucosaminidase gene without the codon of the signal peptide was obtained by PCR with forward primer, 5' GAGCAAGCTTTGCCGCGTATACCGACTACTCA $3^{\prime}$, and reverse primer, 5' CTGAGCTGCTCCGTAAGCT'T 3'; the boldface type indicates the inserted sequence and the underlining indicates a HindIII site. pG1, expressing protein G1, was then constructed by subcloning a $360 \mathrm{bp}$ HindIII fragment from the PCR product which contains codons 28-148 of the glucosaminidase gene into the HindIII site of pEH4 (Fig. 2). This resulted in the addition of seven alien amino acids instead of the 27 amino acid residues for the signal peptide of the glucosaminidase.

pG2, expressing protein $G 2$, was constructed by subcloning the Klenow-treated $2.4 \mathrm{~kb}$ HindIII-EcoRV fragment of pEH4 into the HincII site of pUC118. A plasmid, pG3, expressing protein G3 was obtained by inserting a $2 \cdot 2 \mathrm{~kb} X \mathrm{~cm} \mathrm{I}-$ EcoRV fragment of $\mathrm{pEH} 4$, which was blunt-ended with $\mathrm{T} 4$ polymerase, into the SmaI site of pUC119. The $1.8 \mathrm{~kb}$ Pst I-EcoRV fragment of pEH4, after being blunt-ended with T4 polymerase, was inserted into the SmaI site of pUC118 to obtain plasmid pG4. pG5 and pG6 were obtained by subcloning the Klenow-treated $1.5 \mathrm{~kb} B s r \mathrm{FI}-E c o \mathrm{RV}$ and $1.24 \mathrm{~kb} A v a \mathrm{I}-\mathrm{E} c o \mathrm{RV}$ fragments of pEH4 into the SmaI sites of pUC119 and pUC118, respectively. The $1.0 \mathrm{~kb}$ AvaII-EcoRV fragment, which was end-filled by Klenow treatment, was inserted into the $S$ mal site of pUC118 to obtain pG8. The $1.17 \mathrm{~kb}$ PvuII-EcoRV and $0.8 \mathrm{~kb} B a m \mathrm{HI}$ fragments were used to obtain plasmids $p G 7$ and pG9 by subcloning them into the $S m a I$ and BamHI sites of pUC119 and pUC118, respectively.

Controlled expression of modified glucosaminidases in $E$. coli. E. coli JM109 harbouring different plasmids was cultured in LB medium plus $50 \mu \mathrm{g}$ ampicillin $\mathrm{ml}^{-1}$ with shaking at $37^{\circ} \mathrm{C}$. IPTG (final concentration, $0.1 \mathrm{mM}$ ) was added when the cell density reached $\mathrm{OD}_{660} 0 \cdot 6$. After further incubation for $1 \mathrm{~h}$, the cells were quickly harvested by centrifugation. If incubation was continued for more than $1 \mathrm{~h}$ after the addition of IPTG, $E$. coli cells were found to lyse rapidly in the case of all plasmids except pG8 and pG9. Thus, even in the absence of signal sequence, modified glucosaminidases were very toxic for $E$. coli. Different samples were prepared as follows. For preparing an SDS-extract sample (extract $S), 1 \mathrm{ml}$ culture $\left(\mathrm{OD}_{660} 1\right)$ was pelleted by centrifugation, and the cell pellet was then suspended in a mixture of distilled water $(100 \mu \mathrm{l})$ and SDS-PAGE sample buffer $(100 \mu \mathrm{l})$. After boiling at $100{ }^{\circ} \mathrm{C}$ for $5 \mathrm{~min}$, cell debris was pelleted by centrifugation and the supernatant was used as extract $\mathrm{S}$. For $\mathrm{LiCl}$-extracts, cell pellets from $50 \mathrm{ml}$ cultures were suspended in $5 \mathrm{ml} 5 \mathrm{M} \mathrm{LiCl} /$ buffer $\mathrm{T}$ solution, followed by ultrasonication $(30 \mathrm{~s}, 10 \times)$. After separation of cell debris, the supernatant $(0.5 \mathrm{ml})$ was used as a crude extract (extract $A)$. The rest of the crude extract $(4.5 \mathrm{ml})$ was used for cell-wall-binding assays $(20 \mathrm{mg} M$. luteus cell wall). Cell-wall-binding proteins were re-extracted with $1 \mathrm{ml} 5 \mathrm{M} \mathrm{LiCl} /$ buffer $\mathrm{T}$ solution and the supernatant was used as a cell-wall extract (extract B).

SDSPAGE and zymography. SDS-PAGE of proteins was performed in $12 \%(\mathrm{w} / \mathrm{v})$ polyacrylamide gels as described by Laemmli (1970). Zymography was performed essentially as described by Leclerc \& Asselin (1989), using an SDS-polyacrylamide gel containing $0 \cdot 1 \%(\mathrm{w} / \mathrm{v}) M$. luteus cell wall as a substrate.

Assays for the stability and stimulation of the glucosaminidase and effect of inhibitors on the enzyme activity. The stability of the glucosaminidase was assayed by incubating the enzyme (extract $\mathrm{B}, 100 \mu \mathrm{l}$ ) in a $0.25 \mathrm{M} \mathrm{LiCl} /$ buffer T $(25 \mathrm{mM}$ Tris $/ \mathrm{HCl}$, pH $7 \cdot 2$ ) solution at $37{ }^{\circ} \mathrm{C}$ with slow shaking for various times. The purification of $\mathrm{LytB}$ and the assay for stimulation toward the glucosaminidase were performed according to Kuroda \& Sekiguchi (1992) and Kuroda et al. (1992a), respectively, The effect of the inhibitors EDTA, 2mercaptoethanol, PMSF, diisopropyl fluorophosphate, diethyl 
pyrocarbonate and $N$-ethylmaleimide on the enzyme activity was determined using $M$. luteus cell wall as a substrate.

Swarm plate assay. Swarm plate assay was performed on soft agar plates ( $0.3 \%$ agar). Tryptone and minimal medium swarm plates containing mannitol as an attractant were prepared as described by Rosario et al. (1994) and Màrquez et al. (1990), respectively. Cells from overnight cultures $(1 \mu \mathrm{l})$ were spotted onto swarm plates, and swarm formation was allowed to proceed for $8-12 \mathrm{~h}$ at $37^{\circ} \mathrm{C}$.

Other methods. Transformation of E. coli was performed as described by Sambrook et al. (1989). B. subtilis transformation was performed by the competent cell method (Anagnostopoulos \& Spizizen, 1961), and the protoplast transformation method (Akamatsu \& Sekiguchi, 1987a, b). Cell lysis in buffer was measured according to the method of Svarachorn et al. (1989). Southern and colony hybridizations were performed as described by Sambrook et al. (1989). Protein was determined using $\mathrm{BCA}$ protein assay reagent (Pierce), with BSA as a standard. Assays for competence, sporulation and germination of autolysin-deficient strains were performed according to the methods of Kuroda \& Sekiguchi (1991).

\section{RESULTS}

\section{Purification of the glucosaminidase to apparent homogeneity}

The major glucosaminidase of $B$. subtilis AC327 was extracted from intact cells with a $5 \mathrm{M} \mathrm{LiCl} /$ buffer $\mathrm{T}$ solution, and the resultant crude enzyme (extract A) was bound to and eluted from $M$. luteus cell walls to obtain a partially purified enzyme (extract B). Then extract B was concentrated by ultrafiltration and subjected to gel filtration on a Toyopearl HW-55 column. On gel filtration, the specific activity was $26000 \mathrm{U} \mathrm{mg}^{-1}$, having increased about 2200 -fold, and the enzyme recovery was $11 \%$ (Table 2). The homogeneity of the glucosaminidase was determined by SDS-PAGE, which gave a single band of $90 \mathrm{kDa}$ (Fig. 1a, lane 4). The glucosaminidase was present in a much lower amount compared to the major amidase in vegetative cells (as judged by SDS-PAGE of LiCl-extractable proteins), which is consistent with the previous study (Fan \& Beckman, 1972). The purified glucosaminidase was added to the $M$. luteus cell walls and the mixture was incubated at $37{ }^{\circ} \mathrm{C}$ for various times. The products resulting from the enzymic hydrolysis were investigated by the modified Park \& Johnson method (a)

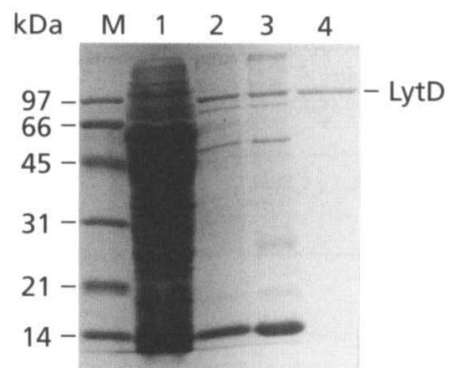

(b)

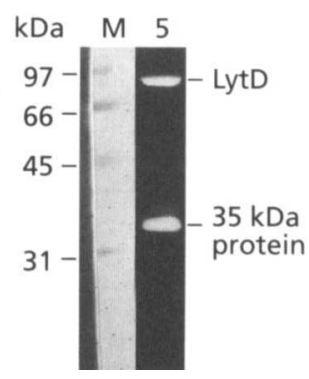

Fig. 1. SDS-PAGE of proteins at different steps of purification of the glucosaminidase (a), and zymography of the purified glucosaminidase (LytD) (b). Lane $M$, protein standards [1.5 $\mu \mathrm{g}$ of each protein for panel (a) and $1.0 \mu \mathrm{g}$ of each protein for panel (b), BioRad], the molecular masses of which are shown at the left. Lane 1, $5 \mathrm{M} \mathrm{LiCl}$ crude extract (extract A, $120 \mu \mathrm{g}$ protein); lane 2, M. luteus cell wall extract (extract $B, 37.5 \mu \mathrm{g}$ ); lane 3, concentrated extract (extract $C, 9 \mu \mathrm{g}$ ); lanes 4 and 5 , LytD fractions obtained by Toyopearl HW- 55 column chromatography (HW-55 fractions, 3 and $2 \mu \mathrm{g}$, respectively). Electrophoresis was in $12 \%$ SDS-polyacrylamide gels and proteins were stained with CBB. The zymographic gel (b) contained $0.1 \%(w / v) \quad M$. luteus cell wall as the enzyme substrate. After SDS-PAGE, the glucosaminidase protein in the zymographic gel (b, lane 5) was renatured by treatment with buffer $\mathrm{T}(25 \mathrm{mM}$ Tris/ $\mathrm{HCl}, \mathrm{pH} \mathrm{7 \cdot 2)}$ and $1 \%(\mathrm{v} / \mathrm{v})$ Triton X-100. Before being photographed, the zymographic gel (b, lane 5 ) was stained with methylene blue $(0.1 \%, w / v)$ in $0.01 \%(w / v)$ $\mathrm{KOH}$.

(Thompson \& Shockman, 1968). Free reducing groups were liberated during the enzyme reaction (data not shown). Therefore, this protein is a glycosidase. Surprisingly, zymographic analysis of the purified glucosaminidase revealed another lytic activity at about $35 \mathrm{kDa}$ in addition to the $90 \mathrm{kDa}$ activity (Fig. 1b, lane 5), but no protein band corresponding to this $35 \mathrm{kDa}$ activity on Coomassie Brilliant Blue (CBB)-staining of the SDSPAGE gel was detected (Fig. 1a, lane 4).

\section{Cloning of the glucosaminidase gene in $E$. coli}

Previously, we reported the cloning of a $3.8 \mathrm{~kb}$ HindIIIEcoRI DNA fragment containing, at least, a part of the glucosaminidase gene (Rashid et al., 1993). A $0.4 \mathrm{~kb}$ Pst $\mathrm{I}$

Table 2. Purification of the glucosaminidase

\begin{tabular}{|c|c|c|c|c|c|}
\hline Fraction & $\begin{array}{l}\text { Volume } \\
\text { (ml) }\end{array}$ & $\begin{array}{l}\text { Activity } \\
\left(\mathrm{U} \mathrm{ml}^{-1}\right)\end{array}$ & $\begin{array}{l}\text { Total } \\
\text { activity } \\
\text { (U) }\end{array}$ & $\begin{array}{l}\text { Specific } \\
\text { activity } \\
\left(\mathrm{U} \mathrm{mg}^{-1}\right)\end{array}$ & $\begin{array}{c}\text { Yield } \\
(\%)\end{array}$ \\
\hline $5 \mathrm{M} \mathrm{LiCl}$ extract & 500 & 14 & 7000 & $11 \cdot 7$ & 100 \\
\hline $\begin{array}{l}\text { M. luteus cell wall } \\
\text { extract }\end{array}$ & 100 & 30 & 3000 & 400 & 43 \\
\hline Concentrated extract & 7 & 128 & 900 & 2140 & 13 \\
\hline $\begin{array}{l}\text { Gel filtration on } \\
\text { Toyopearl HW-55 } \\
\text { column }\end{array}$ & 10 & 78 & 780 & 26000 & 11 \\
\hline
\end{tabular}




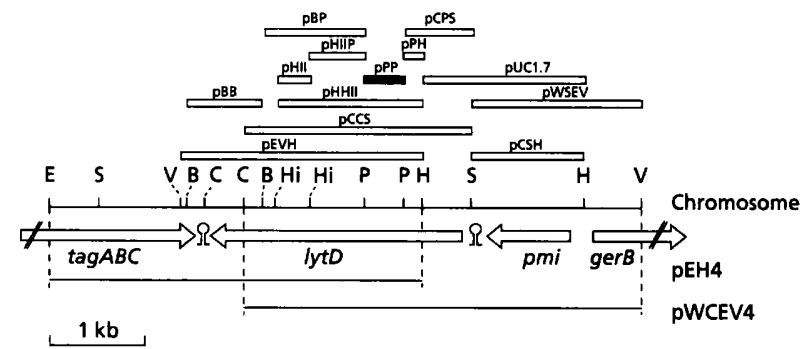

Fig. 2. Physical map of the chromosomal region encompassing lytD, the structural gene of the major endo- $\beta-N$ acetylglucosaminidase of $B$. subtilis AC327. pEH4 is a pUC119derivative containing a $3.8 \mathrm{~kb}$ HindIII-ECORI insert of $B$. subtilis chromosomal DNA (Rashid, 1993; Rashid et al., 1993). pWCEV4 contains another $4.1 \mathrm{~kb}$ EcoRV-Clal insert of $B$. subtilis chromosomal DNA in pMW118 (this study). Large open arrows indicate the coding regions of the respective genes with their transcriptional directions. Stem-loop structures indicate putative rho-independent terminators. The $\operatorname{tag} A B C$ and ger $B$ operons are depicted on the basis of the nucleotide sequence data obtained by Mauel et al. (1991) and Corfe et al. (1994), respectively. The $0.4 \mathrm{~kb}$ Pstl fragment (filled bar) was used for insertional mutagenesis of the lytD gene (Rashid, 1993; Rashid et al., 1993). Open bars with plasmid names above the chromosomal map indicate the segments of pEH4 and pWCEV4 inserted into the corresponding plasmids. Restriction sites: $B$, BamHI; C, Clal; E, EcoRl; H, Hindlll; Hi, Hincll; P, Pstl; S, Sphl; V, ECORV.

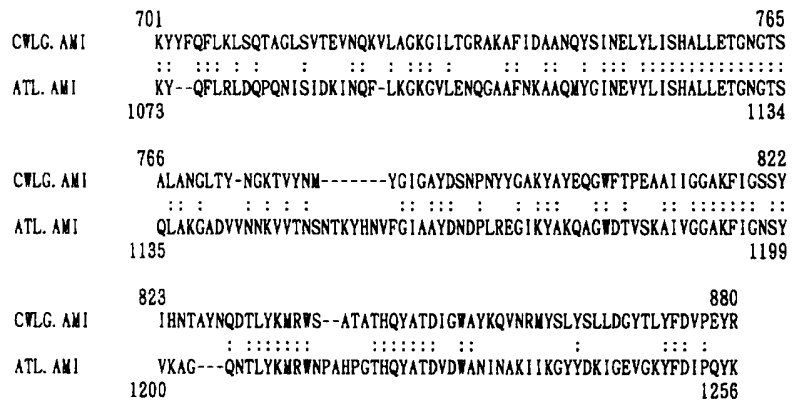

Fig. 3. Alignment of the deduced C-terminal amino acid sequences of the $B$. subtilis LytD ( 880 residues) and the glucosaminidase (GL) domain of $S$. aureus Atl (Oshida et al., 1995; 1256 residues). Colons indicate identical amino acid residues and hyphens represent breaks introduced to maximize similarity. Amino acids are numbered from the $\mathrm{N}$-termini of the proteins.

fragment, which is internal to the glucosaminidase gene (Rashid et al., 1993), was located $0.23 \mathrm{~kb}$ away from the HindIII site in pEH4 (Fig. 2) and hybridized with probe $\mathrm{B}$ (Rashid et al., 1993). Probe B was designed according to the amino acid sequence of an internal $34 \mathrm{kDa} C \mathrm{CNB}-$ peptide of the glucosaminidase (Rashid et al., 1993). These observations together suggested that the whole region of the glucosaminidase gene cannot be located in the $3.8 \mathrm{~kb}$ HindIII-EcoRI cloned fragment of pEH4 (Rashid, 1993). Nucleotide sequencing of the region encompassing the HindIII and EcoRV sites in pEH4 indicated that the glucosaminidase gene is truncated at its $5^{\prime}$-terminus (Fig. 2 and below).
From Southern hybridization analysis of B. subtilis AC327 chromosomal DNA, using the $0.4 \mathrm{~kb} \alpha_{-}{ }^{32}$ P-labelled Pst $\mathrm{I}$ fragment as a probe, it was concluded that a $4.5 \mathrm{~kb} E c o R V$ DNA fragment contains the intact glucosaminidase gene (data not shown). But an attempt to clone this DNA fragment in $E$. coli was unsuccessful. This raised the question of the possible toxicity of the glucosaminidase gene for $E$. coli. Therefore, we cloned a $4.1 \mathrm{~kb}$ EcoRV-ClaI DNA fragment containing the $5^{\prime}$-to-central region of the glucosaminidase gene by colony hybridization into the $S \mathrm{maI}-A c c \mathrm{I}$ site of pMW118 (a low copy vector), the resultant plasmid being designated $\mathrm{pWCEV4}$. Thus, the glucosaminidase gene was cloned in E. coli as a $5^{\prime}$-terminally truncated form in $\mathrm{pEH} 4$ and as a $3^{\prime}$-terminally truncated form in pWCEV4, and, therefore, was not expressed in E. coli in an active form (Fig. 2).

\section{Nucleotide sequencing and structure of the glucosaminidase region}

The basic approach used to construct plasmid derivatives for sequencing was to exploit the restriction enzyme sites present in the insert for subcloning into pUC118. This forced subcloning strategy, in combination with random subcloning for a $1.2 \mathrm{~kb}$ HindIII-SphI fragment, enabled complete sequence determination of the $4 \cdot 2 \mathrm{~kb}$ HindIIIEcoRV fragment, and partially from the EcoRI site of pEH4 and from the EcoRV site of pWCEV4. The restriction enzyme map and location of potential ORFs are shown in Fig. 2.

Computer analysis of the 4162 bp sequence encompassing the right HindIII and left EcoRV sites revealed two ORFs, designated $p m i$ and $l y t D$, transcribed in the same direction as two monocistronic operons (Fig. 2). The lytD ORF encodes a highly basic (pI 10.1) polypeptide of 880 amino acid residues with a molecular mass of $95.6 \mathrm{kDa}$. The $\mathrm{N}-$ terminal amino acid sequences of the mature glucosaminidase protein and a $\mathrm{CNBr}$-peptide derived from it, which had previously been determined (Rashid et al., 1993), were found in the deduced amino acid sequence of the lyt $D$ gene. The $\mathrm{N}$-terminal amino acid sequence of the mature protein corresponds to the derived polypeptide sequence beginning at amino acid 28 . Thus, the preprotein may be cleaved, during or after translocation across the cell membrane, by a signal peptidase after $\mathrm{Ala}_{27}$ in the sequence, $\mathrm{Ala}_{25}-\mathrm{Gln}_{26}-\mathrm{Ala}_{27}-\mathrm{Ala}_{28}$. Typical features of a signal peptide were conserved in the putative leader peptide of the glucosaminidase (Nagarajan, 1993). There are two types of direct repeats, each type being present twice, in the N-terminal-to-central region of the glucosaminidase, and separated by an insertion of 226 amino acid residues (Fig. 6). A computer search for sequence similarity with the glucosaminidase revealed significant similarity with the glucosaminidase (GL) domain of Staphylococcus aureus Atl autolysin (Fig. 3) (Oshida et al., 1995), but no similarity was found with the glucosaminidases of Streptomyces plicatus (Robbins et al., 1984) and Flavobacterium sp. (Takegawa et al., 1991). The degree of identity is $51 \%$ for 177 amino acids between the Cterminal catalytic domain of $\mathrm{LytD}$ and the $\mathrm{C}$-terminal part of Atl glucosaminidase (GL) domain (Fig. 3). pmi(orf X) 


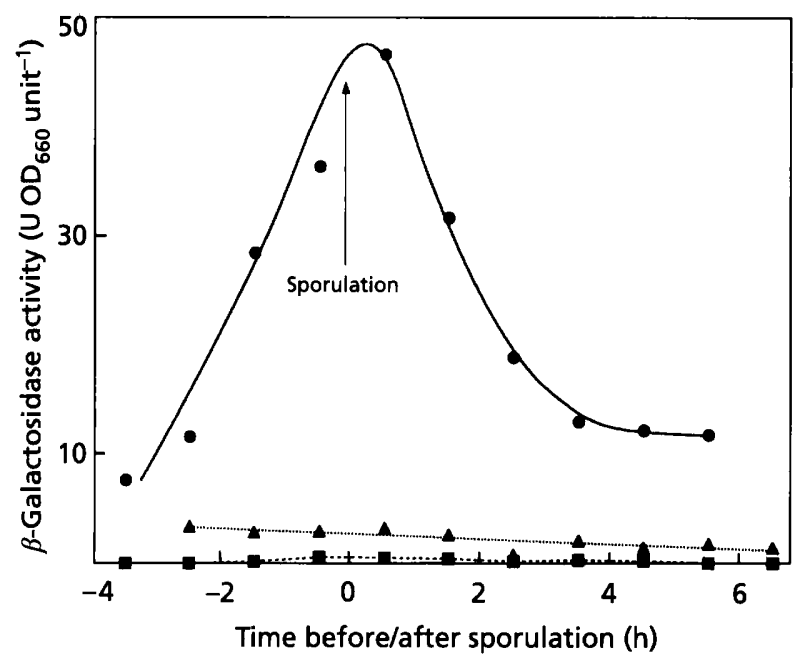

Fig. 4. Expression of a lytD-lacZ transcriptional fusion protein and effect of a sigD null mutation on its expression. Cells were cultured in Schaeffer's sporulation medium at $28^{\circ} \mathrm{C}$. IytD promoter-driven $\beta$-galactosidase activity was measured at the indicated times relative to the start of sporulation $\left(t_{0}\right)$ in $B$. subtilis 680GL20 (lytD-lacZ) (O), 680GL22 (lytD-lacZ sigD::tet) $(\Delta)$, and parent strain, $1 A 680(\mathbb{G}) \cdot t_{0}$ was defined as the point at which cell growth was no longer exponential. These data are representative of two independent experiments.

located upstream of $l y t D$, encodes an acidic (pI 4.94) polypeptide of 316 amino acid residues with a molecular mass of $35.4 \mathrm{kDa}$. A computer search revealed significant amino acid sequence similarity between the Pmi, and the E. coli $\operatorname{man} A$ (Miles \& Guest, 1984) and Salmonella typhimurium pmi (Collins \& Hackett, 1991) gene products (not presented). Each gene product is the phosphomannose isomerase of the respective organism, and interconverts mannose 6-phosphate and fructose-6-phosphate. Thus, the $p m i$ gene product may be the phosphomannose isomerase of $B$. subtilis.

\section{Expression of a lytD-lacz fusion gene in the wild- type and the sigD-deficient strains}

To study the expression of the glucosaminidase gene in vivo, a lytD-lac $Z$ transcriptional fusion gene was constructed and integrated (see Methods) into the chromosome of B. subtilis $1 \mathrm{~A} 680$, which has a reduced level of endogenous $\beta$-galactosidase activity (Errington \& Vogt, 1990 ). To confirm the proper integration event, chromosomal DNA from B. subtilis 680GL20 and a control, $1 \mathrm{~A} 680$, were extracted and Southern hybridized with pDEB1G as a probe. Upon PstI digestion, one hybridizing band at $5.5 \mathrm{~kb}$ for $B$. subtilis $1 \mathrm{~A} 680$, and two hybridizing bands at 2.7 and $17 \mathrm{~kb}$ for $B$. subtilis $680 \mathrm{GL} 20$ confirmed the Campbell-type integration of pDEB1G for $B$. subtilis 680GL20 (data not shown). Upon PstI and HindIII digestion, one hybridizing band at $1.7 \mathrm{~kb}$ for $B$. subtilis $1 \mathrm{~A} 680$, and three hybridizing bands at $0.8,1.7$ and $11.7 \mathrm{~kb}$ for $B$. subtilis $680 \mathrm{GL} 20$ also supported the integration event (data not shown). Màrquez et al. (1990) reported the reduction of glucosaminidase activity in a sigD null mutant strain and our preliminary observation of the upstream nucleotide sequence of the glucosaminidase gene revealed a $\sigma^{\mathrm{D}}$-type promoter sequence (Arnosti \& Chamberlin, 1989; Helmann, 1991) upstream of the glucosaminidase gene. Therefore, we decided to introduce a sigD null mutation into the chromosome of $B$. subtilis 680GL20, as follows. A $1.5 \mathrm{~kb}$ EcoRI-HindIII DNA fragment containing a $\mathrm{Tc}^{\mathrm{r}}$ gene $(t e t)$ from pUCTC (Rashid et al., 1993) was inserted into the unique EcoT14I site of the sigD gene, resulting in plasmid pSDTC. The $3.0 \mathrm{~kb}$ sigD:: tet gene cluster was purified and inserted into the chromosome of $B$. subtilis $680 \mathrm{GL} 20$ by the conventional method. A double-crossover recombination event disrupted the chromosomal copy of the $\operatorname{sig} D$ gene resulting in the $\mathrm{Tc}^{\mathrm{r}}$ B. subtilis $680 \mathrm{GL} 22$ strain. Filamentous growth and non-motility of strain 680GL22 served as confirmation of sigD disruption (Màrquez et al., 1990).

Fig. 4 shows the time course of expression of the lytD-lac $Z$ transcriptional fusion gene. In the parent strain, $B$. subtilis 680GL20, the fusion gene expression started from the early exponential growth phase, reaching a maximum at the onset of sporulation $\left(t_{0}\right)$ and then sharply decreased. This type of temporal expression is characteristic of SigDdependent genes, including those of flagellin (bag) and major amidase (lytC) (Mirel \& Chamberlin, 1989; Kuroda $\&$ Sekiguchi, 1993). A low level of $\beta$-galactosidase activity (about $5 \%$ of that of strain 680GL20 at $t_{0}$ ) was observed for SigD-deficient strain 680GL22, which was almost growth-phase independent and certainly higher than that of the control strain, 1A680 (Errington \& Vogt, 1990). Thus, the glucosaminidase gene probably has another minor promoter activity in addition to a major $\sigma^{\mathrm{D}}$-like promoter activity.

\section{Physiological roles of the glucosaminidase and/or the amidase in B. subtilis}

A search for the physiological functions of the glucosaminidase and/or the amidase revealed that these two abundant activities are not required, either singly or in concert, for competence, sporulation and germination, as measured by conventional methods. Cellular autolysis was studied by (i) suspending exponentially growing cells $\left(\mathrm{OD}_{660} 0.3\right)$ in a buffer optimized for the measurement of the glucosaminidase or the amidase activity, (ii) continuing the culture for a prolonged time to measure stationary phase lysis, and (iii) exposing exponentially growing cells $\left(\mathrm{OD}_{660} 0 \cdot 3\right)$ to cold-shock treatment (unpublished results). With all the methods tested, cellular autolysis was found to depend mainly on the amidase (unpublished results). The absence of both endolysins did not significantly alter the lytic action of penicillin toward exponentially growing cells (not presented). Inactivation of either the amidase or the glucosaminidase led to a modest reduction in swarm diameter (Table 3). In contrast, the double mutants, strains AGB1 and 168GB1, had greatly reduced swarm diameter $(30-34 \%$ of the wild-type diameter). However, the synthesis of flagellin protein in the mutant strains was not affected, as judged 
Table 3. Swarm plate assay of the autolysin-deficient strains

\begin{tabular}{|c|c|c|c|}
\hline \multirow[t]{2}{*}{ Strain } & \multirow[t]{2}{*}{ Characteristic(s) } & \multicolumn{2}{|c|}{$\begin{array}{l}\text { Swarm diameter } \\
(\% \text { wt } \pm \text { SEM })^{*}\end{array}$} \\
\hline & & Mannitol & Tryptone \\
\hline $\mathrm{AC} 327$ & Wild-type & $100 \pm 2 \cdot 3$ & $100 \pm 2 \cdot 8$ \\
\hline AG1 & LytD $^{-}$ & $56 \pm 0.9$ & $65 \pm 1 \cdot 7$ \\
\hline AN8 & $\mathrm{CwlB}^{-}$ & $67 \pm 1 \cdot 9$ & $51 \pm 1 \cdot 4$ \\
\hline AGB1 & LytD $^{-} \mathrm{CwlB}^{-}$ & $34 \pm 0 \cdot 2$ & $33 \pm 0 \cdot 9$ \\
\hline 168 & Wild-type & $100 \pm 1 \cdot 8$ & $100 \pm 3.6$ \\
\hline 168G1 & $\mathrm{LytD}^{-}$ & $54 \pm 1 \cdot 9$ & $72 \pm 1 \cdot 5$ \\
\hline $168 \mathrm{~N} 8$ & $\mathrm{CwlB}^{-}$ & $63 \pm 0.9$ & $64 \pm 2 \cdot 1$ \\
\hline $168 \mathrm{~GB} 1$ & $\mathrm{LytD}^{-} \mathrm{CwlB}^{-}$ & $32 \pm 0.5$ & $30 \pm 0 \cdot 8$ \\
\hline
\end{tabular}

* Swarm diameter was measured after $8-12 \mathrm{~h}$ on $0.3 \%$ agar plates containing either tryptone or minimal medium with mannitol. SEM equals $\sigma_{n-1} / \sqrt{n}$ (Rosario et al., 1994), where $n=10$.

by SDS-PAGE analysis (not presented). Thus, the precise roles of these endolysins in flagellation (motility) remain obscure.

\section{Recombinant glucosaminidase in B. subtilis AG1 (lytD)}

Plasmid pHYG contains the intact glucosaminidase gene, and plasmid $\mathrm{pHYEB}$ contains a truncated form of the glucosaminidase gene in which the $3^{\prime}$-terminal 187 codons of the native glucosaminidase gene have been replaced by 19 alien codons of the vector (Fig. 6b). Plasmid pHYG could not be constructed in E. coli. We also did not succeed in constructing an intact glucosaminidase-producing plasmid in a low copy vector (pMW118). These observations confirmed our suspicion that the intact glucosaminidase is lethal for E. coli, even at a low copy number (five copies per cell). B. subtilis AG1 harbouring plasmid pHYG, pHYEB or, as a control, pHY300PLK was cultured in $\mathrm{BP}$ medium for $12 \mathrm{~h}$ at $28^{\circ} \mathrm{C}$ and samples (extracts A and B) were then prepared as previously described (Rashid et al., 1993). SDS-PAGE analysis of extracts $A$ and $B$ demonstrated the production of the intact glucosaminidase protein, and its amplification upon binding and elution from $M$. luteus cell wall (Fig. 5a, lanes 2 and 5). The truncated form of the glucosaminidase $[\mathrm{tLytD}(\mathrm{G} 10)]$ also remained tightly bound to the cell wall (Fig. 5a, lane 3), and the estimated molecular mass was less than the predicted size by about $14 \mathrm{kDa}$. However, in contrast to the intact glucosaminidase, this truncated glucosaminidase [tLytD(G10)] exhibits no catalytic activity toward cell wall, as seen by zymographic analysis (Fig. 5b, lanes 3 and 6).

Previously, we reported the disappearance of the lytic activities of several fast-migrating proteins (FMPs) of about $35-39 \mathrm{kDa}$ in addition to one of $90 \mathrm{kDa}$ for strain AG1 on zymography (Rashid et al., 1993). As Fig. 5(b) shows, lytic activities of FMPS were found in addition to
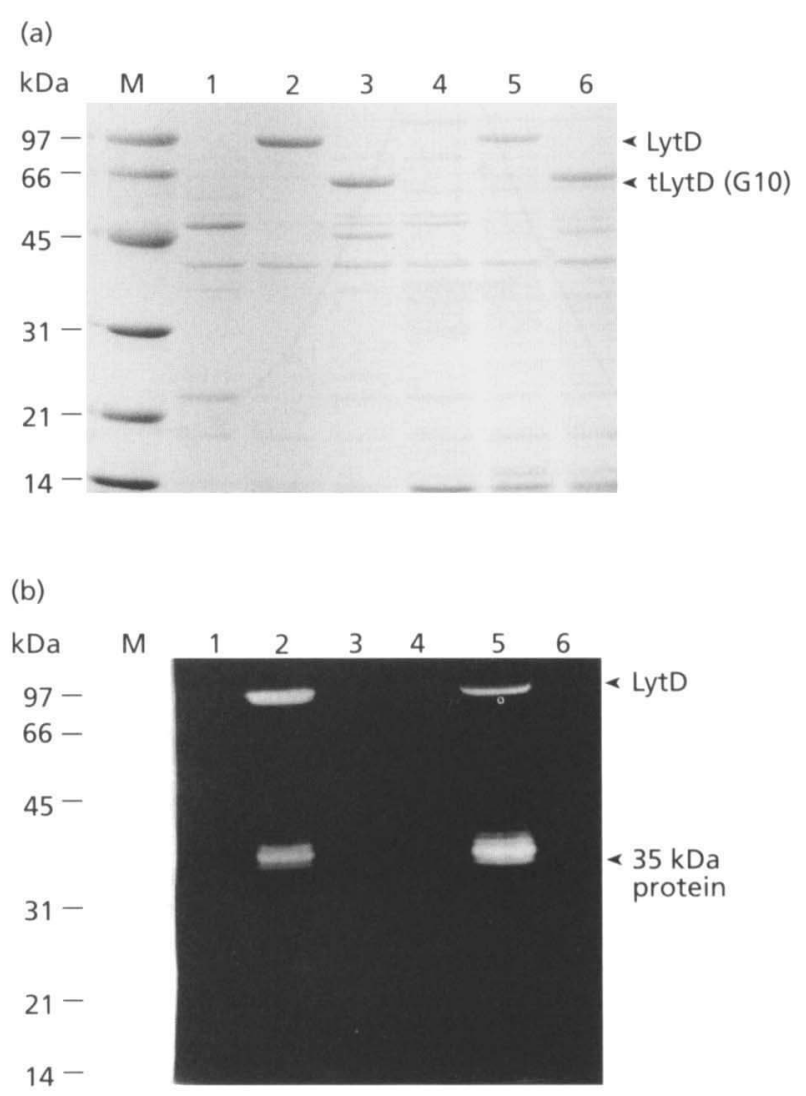

Fig. 5. SDS-PAGE (a) and zymography (b) of the recombinant glucosaminidase protein produced in B. subtilis AG1 (lytD). The electrophoretic conditions and renaturation of proteins after electrophoresis (b) were as in the legend to Fig. 1. $\mathrm{LiCl}(5 \mathrm{M})$ crude extract (extract A) and cell-wall-extract (extract B) samples were prepared as previously described (Rashid et al., 1993b). Lanes: M, protein standards (BioRad); 1-3, extract B samples; 4-6, extract $A$ samples; 1 and $4, B$. subtilis AG1 (pHY300PLK); 2 and $5, B$. subtilis AG1(pHYG); 3 and $6, B$. subtilis AG1(pHYEB). The wild-type glucosaminidase protein ( $90 \mathrm{kDa})$ and activity (90 and $35 \mathrm{kDa}$ ) bands, and the truncated glucosaminidase (tLytD/G10) protein $(63 \mathrm{kDa})$ band are indicated by arrowheads on the right.

that of the $90 \mathrm{kDa}$ one for both extracts $\mathrm{A}$ and $\mathrm{B}$ (lanes 2 and 5). Protein bands corresponding to these activities could not be detected upon CBB staining (Fig. 5a) of the SDS-polyacrylamide gel. It is presumed that a certain amount of the intact glucosaminidase protein is processed in vivo to the FMPs by proteolytic cleavage. The activities of the FMPs were not amplified upon cell-wall-binding (Fig. 5b, compare lanes 2 and 5), whereas the $90 \mathrm{kDa}$ activity was amplified.

\section{Characterization of the truncated glucosaminidase proteins produced in E. coli}

Enzymic characterization of the truncated glucosaminidase proteins (Fig. 6b) by zymographic analysis is presented in Fig. 7. Crude SDS-extract (extract S) samples prepared from equal amounts of E. coli cells harbouring various plasmids were loaded together with a control. For 
(a)

A1 81 SGIHSESEAKAILSGLAKQTSITGTSSPVGSKOPYVTISSGAISGERQANTI 132 $* * *: \quad * *:: \quad * * * * * *: \quad *: \quad * * * * * *: * *$ A2 161 SDIADETKVKALIQSLAKQTGIKSSYQPITHTVSVTTIQSGTIVGDSRAAQI 212

B1 439 ITTESLLDQTKVNQALTFFKSNHISVASQRTGQTA 473 $* * * *:: *:: * * * * * * * * *: * * * * * * *$

B2 479 ITTEAIISQEEIDRVLTFFKQNHIAVTTSKTGQTA 513 (b)

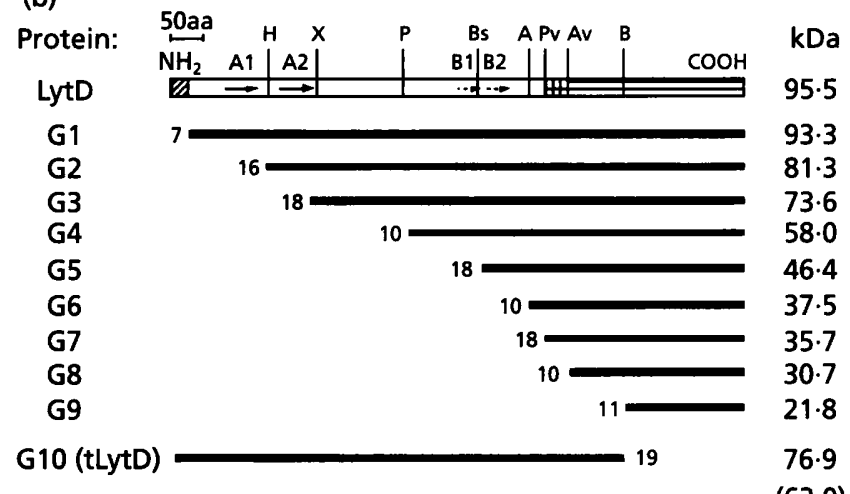

$95 \cdot 5$

$93 \cdot 3$

58.0

$46 \cdot 4$

$37 \cdot 5$

$35 \cdot 7$

$21 \cdot 8$

$(63 \cdot 0)$

Fig. 6. Intramolecular repeated sequences in the $\mathrm{N}$-terminal-to-central region of the glucosaminidase (a), and the primary structure and serial deletions of the glucosaminidase (b). A1 and A2, and B1 and B2 are two distinct types of tandemly repeated sequences, and are separated by an insertion of 226 amino acids. The numbers at the left or right of the direct repeat sequences (a) are the positions with respect to the $\mathrm{N}$-terminal amino acid of the glucosaminidase. Identical, similar (conservative substitutions) and unrelated amino acids are indicated by stars, colons and spaces, respectively. Conservative substitutions are: $I, L, V$ and $M ; K$ and $R ; S$ and $T ; D$ and $E ; F$ and $Y ; N$ and $Q ; G$ and $A$. The numbers at the left or right of the truncated proteins (b) indicate alien amino acids. Hatched and rectangular regions indicate the signal peptide and catalytic domain of the glucosaminidase, respectively. The square region between Pvull and Avall sites indicates a putative 38 amino acid processing region for the activities of FMPs on zymography (Figs $1 \mathrm{~b}, 5 \mathrm{~b}$ and 7 ). Abbreviations: $A$, Aval; Av, Avall; B, BamHl; Bs, BsrFl; H, HindIII; P, Pstl; Pv, Pvull; X, Xcml.

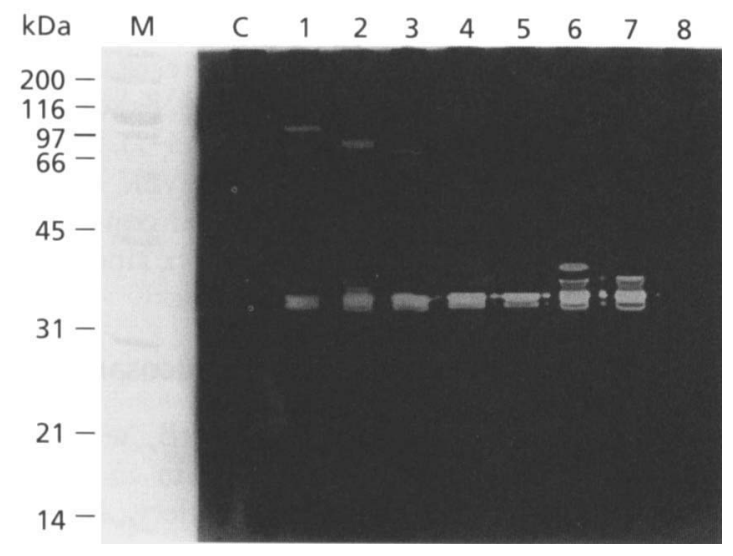

Fig. 7. Zymographic analysis of the truncated glucosaminidase proteins produced in $E$. coli JM109 harbouring different plasmids. Crude SDS-extract samples (extract S) were prepared as described in Methods and loaded on a $12 \%$ SDSpolyacrylamide gel containing $0.1 \%(w / v) M$. luteus cell wall as a substrate. After electrophoresis, the proteins were renatured as previously described (Rashid et al., 1993). The gel was stained with $0.01 \%$ methylene blue in $0.01 \% \mathrm{KOH}$ before being photographed. Lanes: 1-8, proteins G1-G8, respectively; C, control strain, $E$. coli JM109(pUC118). The molecular masses of the protein standards (BioRad) are indicated on the left.

all proteins except $\mathrm{G} 8$, a certain amount was processed to several FMPs that retained lytic activity (lanes 1-7). Proteins G1-G6 exhibited two activities, the activities for the slow-migrating proteins (SMPs) corresponding to those of the proteins of the predicted molecular masses and the activities for the FMPs corresponding to those of the processed ones. The intensities of the activities of FMPs were almost identical for proteins G1-G5. For the activities of SMPs, the intensities for proteins G1 and G2 were almost equal, but those for proteins G3, G4 and G5 gradually decreased. Thus, the loss of more than one repeating unit seemed to drastically reduce the activities of SMPs of the truncated glucosaminidases. However, the activities for SMPs of G6 and G7 and for FMPs of G1-G6, which are devoid of a substrate-binding domain, did not decrease, as judged by zymography (lanes 1-7). This discrepancy may be due to the more efficient renaturation on zymography of the smaller proteins, which completely lack a substrate-binding domain. Protein G8 (lane 8) exhibited no activity on zymographic analysis. We also attempted to characterize these truncated glucosaminidases in terms of their binding affinity to the substrate cell wall. For protein G1, we did not find any apparent change in binding affinity (data not shown). For proteins G2-G7, SMPs and activity bands could not be detected on the respective gels in the case of $\mathrm{LiCl}$ extracts (extracts A and B) (data not shown), although for SDSextract samples (extract $S$ ) they were easily detected (Fig. 7). This may suggest rapid degradation of the truncated glucosaminidases by $E$. coli proteases during the preparation of samples. Previous investigators (Rogers et al., 1984; Brown, 1977; Brown \& Young, 1970) reported that the native glucosaminidase is very sensitive to proteases. Thus, deletions may render the modified glucosaminidases more sensitive to $E$. coli proteases.

\section{In vitro processing of the partially purified glucosaminidase and the activity of processed forms of the glucosaminidase}

Partially purified wild-type glucosaminidase (extract B) from B. subtilis AG1 ( $\mathrm{pHYG}$ ) was used to study the timecourse of processing in vitro. On incubation at $37^{\circ} \mathrm{C}$ for 
(a)

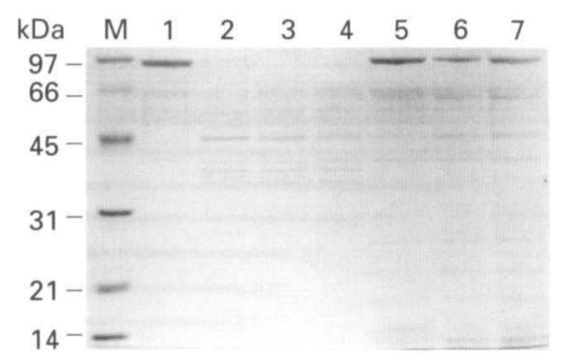

(b)

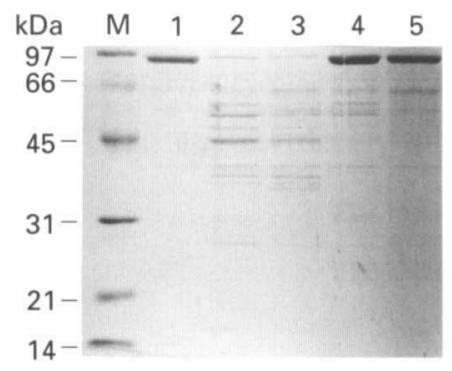

(c)

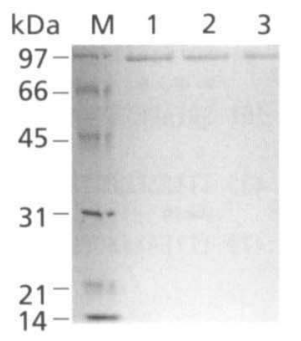

Fig. 8. SDS-PAGE analysis of the stability of the glucosaminidase. (a) The partially purified $90 \mathrm{kDa}$ glucosaminidase (extract B in $5 \mathrm{M} \mathrm{LiCl} /$ buffer T) is degraded to smaller proteins when incubated at $37^{\circ} \mathrm{C}$ after dilution to $0.25 \mathrm{M} \mathrm{LiCl}$ (lanes 2-4). This degradation is inhibited when SDS-purified B. subtilis cell wall $\left(5 \mathrm{mg} \mathrm{ml}^{-1}\right.$ ) was added to the enzyme (for $30 \mathrm{~min}$ on ice) before the start of incubation at $37^{\circ} \mathrm{C}$ (lanes 5-7). (b) When $0.1 \mathrm{mM}$ PMSF was added to the extract B sample, the degradation was also stopped (lanes 4 and 5). (c) When the extract B sample was further purified by gel filtration chromatography, the degradation was also stopped. The electrophoretic conditions were as in the legend to Fig. 1. All incubations were performed in $0.25 \mathrm{M} \mathrm{LiCl} /$ buffer $\mathrm{T}\left(25 \mathrm{mM} \mathrm{Tris} / \mathrm{HCl}, \mathrm{pH} \mathrm{7.2)}\right.$ at $37^{\circ} \mathrm{C}$ for various times, and samples were prepared for loading by $2 \%$ TCA precipitation after incubation. Lane M, protein standards (BioRad). (a) and (b) $100 \mu \mathrm{l}$ extract B sample was loaded in each lane. (a) Lane 1, $0 \mathrm{~h}$ incubation (control); lanes 2, 3 and 4, incubation without cell wall for 1, 2 and $3 \mathrm{~h}$, respectively; lanes 5, 6 and 7, incubation with cell wall for 1,2 and $3 \mathrm{~h}$, respectively. (b) Lane 1, $0 \mathrm{~h}$ incubation (control); lanes 2 and 3, incubation without PMSF for 0.5 and $1.5 \mathrm{~h}$, respectively; lanes 4 and 5 , incubation with $0.1 \mathrm{mM}$ PMSF for 0.5 and $1.5 \mathrm{~h}$, respectively. (c) Lanes 1,2 and 3 , incubation with $150 \mu \mathrm{HW}-55$ fraction for 1,2 and $3 \mathrm{~h}$, respectively.

$1.5 \mathrm{~h}$ in $0.25 \mathrm{M} \mathrm{LiCl} /$ buffer $\mathrm{T}$ solution, the $90 \mathrm{kDa}$ glucosaminidase protein and activity band disappeared with concomitant increases in several FMPs and their activity bands (Fig. 8a, lanes 2-4; 8b, lanes 2 and 3; zymography data not shown). It seems that only a small amount of contaminating protease was sufficient for its degradation. Our in vitro study supports our speculation that the truncated glucosaminidases, produced in E. coli, were very unstable, and hence the cell-wall-binding assay was unsuccessful.

Since the specific activities of the processed proteins (FMPs) seemed to increase in zymographic gels (Figs 1b, $5 \mathrm{~b}$ and 7 ), the partially purified glucosaminidase (extract B) was processed completely in vitro. The cell-wall-lytic activities of these processed proteins were then measured in an aqueous buffer optimized for the glucosaminidase activity (Rogers et al., 1984). The specific activities of these processed proteins did not increase in the aqueous buffer assay system (data not shown). Therefore, possible reasons for the strong activities of the processed proteins in zymographic gels may be efficient renaturation and activation of the processed proteins, and/or the existence of several contiguous proteins $(35-39 \mathrm{kDa})$ which together exhibit a broad, seemingly stronger, activity band.

\section{Stability of the purified glucosaminidase against proteolytic enzymes}

The glucosaminidase was purified to apparent homogeneity from B. subtilis AG1 (pHYG) as described in Methods with the omission of the concentration step by ultrafiltration. This purified enzyme was found to be resistant to degradation compared to the partially purified enzyme (extract B) as shown in Fig. 8(c). However, the partially purified enzyme also became resistant to proteolysis when SDS-purified B. subtilis (Fig. 8a) or M. luteus (not shown) cell walls were added (lanes 5-7). Moreover, the stability of the partially purified enzyme (extract B) was found to increase when PMSF (final concentration, $0.1 \mathrm{mM}$ ) was added to the enzyme (Fig. 8b, lanes 4 and 5).

\section{Biochemical characterization of the glucosaminidase}

B. subtilis cell-wall-binding protein, LytB, was purified and then added to the glucosaminidase in an equimolar amount to test for the stimulatory effect. It did not stimulate the lytic activity of the glucosaminidase (data not shown). Thus, the stimulatory effect of LytB seems to be only specific to the amidases.

The effect of various enzyme inhibitors on the glucosaminidase activity was also tested. No inhibition was observed for PMSF ( $5 \mathrm{mM}$ ), diisopropyl fluorophosphate $(1 \mathrm{mM}), \quad 2$-mercaptoethanol $(25 \mathrm{mM})$ and $N$ ethylmaleimide $(5 \mathrm{mM})$. However, the enzyme was inhibited strongly by diethyl pyrocarbonate which is known to react with active histidine $(33 \%$ at $1 \mathrm{mM}$ and $86 \%$ at $5 \mathrm{mM})$ and only slightly by EDTA ( $7 \%$ at $5 \mathrm{mM}$ and $23 \%$ at $25 \mathrm{mM}$ ). Thus, it seems likely that the His residue(s) of the catalytic domain is important for the catalytic activity of the glucosaminidase.

\section{DISCUSSION}

Rogers et al. (1984) initially reported the purification of the high-molecular-mass autolytic glucosaminidase of $B$. subtilis 168 . They found it to be a dimer of $190 \mathrm{kDa}$ in 
aqueous buffer consisting of identical subunits of $90 \mathrm{kDa}$, and very sensitive to proteolytic enzymes. We simplified the procedure of Rogers $e t$ al. (1984), as follows. (i) The tedious step of isolation of the autolysin-containing native cell walls was eliminated by directly extracting autolysins from the intact cells with a high concentration $(5 \mathrm{M}$ instead of $2 \mathrm{M}$ ) of $\mathrm{LiCl}$, which is a more efficient method (Brown, 1973); (ii) the two-step column chromatography (affinity followed by gel filtration) was replaced by a single-step gel filtration chromatography. During the purification of the glucosaminidase, the growth medium significantly affected the yield, which is consistent with the study of Brown (1977). However, transcriptional studies with a lytD-lac $Z$ fusion gene did not reveal significant dependence on growth medium (not presented). Thus, the difference in yield may be due to translational and/or post-translational phenomena.

Exploiting the amino acid sequences of the purified glucosaminidase, the corresponding gene, lyt $D$, was cloned. Nucleotide sequencing revealed a monocistronic operon encoding a polypeptide of 880 amino acids which is endowed with a typical signal peptide. The existence of the signal peptide was confirmed by $\mathrm{N}$-terminal sequencing of the mature protein (Rashid, 1993; Rashid $e t$ al., 1993). There is a $12 \mathrm{bp}$ nucleotide sequence discrepancy in the upstream non-coding region of $p m i$ between our sequence and that of Margot et al. (1994), which is complementary to each other (nucleotides 48-59 in our accession number D45048). Transcriptional analysis with a $l y t D-l a c Z$ fusion gene revealed that the glucosaminidase gene is transcribed during the early- to late-exponential growth phase. Introduction of a sigD null mutation greatly reduced (by about $95 \%$ ) this expression, suggesting that the glucosaminidase gene is mainly transcribed by an E- $\sigma^{\mathrm{D}}$ holoenzyme. The $f a D$ and $\operatorname{deg} S-\operatorname{deg} U$ pleiotropic mutations may affect transcription of the glucosaminidase gene through the level of the SigD protein, as is the case for the major amidase operon (Kuroda \& Sekiguchi, 1993; Tokunaga et al., 1994). Recently, Mirel et al. (1994) reported identification of the $f g M$ gene product as an anti- $\sigma^{\mathrm{D}}$ factor which represses $\sigma^{\mathrm{D}}$. dependent transcription in response to an unlinked mutation in a gene directing early flagellar synthesis. Thus, the glucosaminidase gene transcription may be affected in the $f a A 4, f l a A 15$ and ifm mutants by the action of the flgM gene product (Pooley \& Karamata, 1984; Barilla et al., 1994; Hauser et al., 1991; Mirel et al., 1994).

Studies with the strains inactivated in the glucosaminidase and/or amidase gene(s) revealed that the glucosaminidase and the amidase are dispensable, either singly or in concert, with respect to growth, morphology, competence, sporulation and germination. The contribution of the amidase to cellular autolysis was several times higher than that of the glucosaminidase, but, with respect to swarming, the contribution of each protein was indistinguishable from the other. The double mutant had greatly reduced swarming compared to the single mutants, which supports our previous result (Rashid et al., 1993). This result is, however, in contradiction with the reports of Margot \& Karamata (1992) and Margot $e t$ al. (1994) suggesting that only the amidase-deficient strain has greatly impaired motility on semi-solid medium. Our amidase-deficient strains in the genetic backgrounds of 168 and AC327 were not as impaired as the double mutant in motility on minimal swarm plates (Màrquez et al., 1990) as well as on tryptone plates containing $0.3 \%$ agar (Table 3 ). The reason for this discrepancy regarding the role of the amidase and glucosaminidase in flagellar motility remains obscure. Since these endolysins are not required for the synthesis of flagellin protein, the earlier hypothesis of Fein (1979) that these activities are required for the morphogenesis of the flagellum basal body does not remain plausible in the light of recent findings (Barilla et al., 1994; Mirel et al., 1994).

Amidases of the genus Bacillus, independent of phage or host origin, are generally composed of two domains - a catalytic domain and a cell-wall-binding domain containing several (usually two or three) tandemly repeated sequences (Kuroda et al., 1992b). Other cell-wall-binding proteins [LytB, a modifier of major amidase, CwlB (Kuroda et al., 1992a); WapA, a major wall-associated protein (Foster, 1992)], which apparently have no catalytic function also contain three tandemly repeated sequences. Interestingly, a stage II sporulation gene, spoIIB, also contains two tandemly repeated sequences homologous to $c w l M$ and $c w l C$ (Margolis et al., 1993; Kuroda et al., 1993). However, the organization of two domains in amidases, i.e. whether the $\mathrm{N}$-terminal domain is catalytic or the C-terminal domain is substrate-binding, is not conserved. In the case of the glucosaminidase, a truncated form ( $\mathrm{tLytD} / \mathrm{G} 10$ ) lacking the C-terminal 187 amino acids still remained tightly bound to cell walls but lacked catalytic activity (Fig. 5). However, another truncated form of the glucosaminidase, protein $\mathrm{G} 7$, containing only the C-terminal 312 amino acids, had catalytic activity (Fig. 7, lane 7). Further truncation (protein G8, 274 amino acids) caused the complete loss of catalytic activity (Fig. 7, lane 8). Thus, it seems that the glucosaminidase, like the amidases, is also composed of two domains, the $\mathrm{N}$-terminal two-thirds for substrate binding and the C-terminal one-third for the catalytic function, and that these domains are functionally independent.

We have demonstrated that FMPs were derived from the intact glucosaminidase upon putative proteolytic processing and included its $\mathrm{C}$-terminal catalytic domain (Figs $1 \mathrm{~b}, 5 \mathrm{~b}$ and 7 ). A region comprising 38 amino acid residues in between the $\mathrm{N}$ - and $\mathrm{C}$-terminal domains has been identified as a putative processing one (Figs $6 \mathrm{~b}$ and 7 ). The molecular mass of $\mathrm{tLytD}(\mathrm{G} 10)$ determined on $\mathrm{CBB}$ staining, which was produced in $B$. subtilis, was about $14 \mathrm{kDa}$ smaller than the predicted one (Fig. 5a). Assuming proteolytic cleavage of $\operatorname{tLytD}(\mathrm{G} 10)$ at the abovementioned region, the discrepancy in molecular mass can be explained. Two B. subtilis proteins (CwlA, an amidase, and WapA) and a B. megaterium autolysin $(29 \mathrm{kDa}$, cortexlytic) are proteolytically processed to smaller forms (Kuroda et al., 1991; Foster, 1991; Foster \& Johnstone, 1988). Two autolytic muramidases (M-1 and M-2) of Entercoccus birae ATCC9790 and one amidase (LytA) of Staphylococcus aureus NCTC8325 have also been reported to 
be proteolytically processed (Kariyama \& Shockman, 1992; Wang et al., 1992). Taking these observations together, the processing of the glucosaminidase is not at all surprising. However, the physiological necessity of this processing remains unclear.

The instability of the partially purified glucosaminidase was due to the residual proteases present in the enzyme mixture (Fig. 8b). Our in vitro study indicates that the cellwall-bound glucosaminidase probably achieves a conformational state which is relatively resistant to proteolytic attacks compared to the glucosaminidase alone (Fig. 8a). A similar phenomenon was also observed for the pneumococcal cell-wall hydrolases (Sanz et al., 1992). In contrast to the amidase genes cloned in this laboratory, the lytD gene product was found to be very toxic to $E$. coli. It is unclear why the glucosaminidase hydrolyses $M$. luteus cell walls more efficiently than $B$. subtilis cell walls in vitro (Fan \& Beckman, 1973; Rashid et al., 1993), though there is no significant difference between the peptidoglycans of these two organisms (L-lysine instead of mesodiamino pimelic acid in the peptide subunit of $M$. luteus; teichuronic acid instead of teichoic acid in $M$. luteus) (Hase \& Matsushima, 1977; Karl \& Kandler, 1972; Nasir-ud-Din et al., 1985). The absence of cysteine residues in the deduced polypeptide of the glucosaminidase gene, the non-inhibition of the glucosaminidase activity by thiol-directed reagents ( $N$-ethylmaleimide and 2 -mercaptoethanol), and the retention of lytic activity by the modified glucosaminidases on zymographic analysis (Fig. 7) raised ambiguity about the dimeric nature of this protein reported by Rogers $e t$ al. (1984). The role of the intervening 226 amino acids between the repeated sequences is also obscure. Experiments will be designed to address these questions in the future.

\section{ACKNOWLEDGEMENTS}

We wish to thank Michael J. Chamberlin, and the Bacillus Genetic Stock Center for kindly providing plasmids pJH6-2 and pLM3, and B. subtilis $1 \mathrm{~A} 680$ and plasmid pDEB1, respectively. M.H.R. wishes to thank the Japanese Ministry of Education, Science and Culture for awarding him a Monbusho scholarship during this study.

\section{REFERENCES}

Akamatsu, T. \& Sekiguchi, J. (1987a). Genetic mapping by means of protoplast fusion in Bacillus subtilis. Mol \& Gen Genet 208, 254-262.

Akamatsu, T. \& Sekiguchi, J. (1987b). Genetic mapping and properties of filamentous mutations in Bacillus subtilis. Agric Biol Chem 51, 2901-2909.

Anagnostopoulos, C. \& Spizizen, J. (1961). Requirements for transformation in Bacillus subtilis. J Bacteriol 81, 741-746.

Arnosti, D. N. \& Chamberlin, M. J. (1989). Secondary $\sigma$ factor controls transcription of flagellar and chemotaxis genes in Escherichia coli. Proc Natl Acad Sci US A 86, 830-834.

Ayusawa, D., Yoneda, Y., Yamane, K. \& Maruo, B. (1975). Pleiotropic phenomena in autolytic enzyme(s) content, flagellation, and simultaneous hyperproduction of extracellular $\alpha$-amylase and protease in a Bacillus subtilis mutant. J Bacteriol 124, 459-469.
Barilla, D., Caramori, T. \& Galizzi, A. (1994). Coupling of flagellin gene transcription to flagellar assembly in Bacillus subtilis. J Bacteriol 176, 4558-4564.

Brown, W. C. (1973). Rapid methods for extracting autolysins from Bacillus subtilis. Appl Microbiol 35, 295-300.

Brown, W. C. (1977). Autolysins in Bacillus subtilis. In Microbiology-1977, pp. 75-84. Edited by D. Schlessinger. Washington, DC: American Society for Microbiology.

Brown, W. C. \& Young, F. E. (1970). Dynamic interactions between cell wall polymers, extracellular proteases and autolytic enzymes. Biochem Biophys Res Commun 38, 564-568.

Collins, L. V. \& Hackett, J. (1991). Sequence of the phosphomannose isomerase-encoding gene of Salmonella typhimurium. Gene 103, $135-136$.

Corfe, B. M., Sammons, R. L., Smith, D. A. \& Mauell, C. (1994). The gerB region of the Bacillus subtilis 168 chromosome encodes a homologue of the ger $A$ spore germination operon. Microbiology 140, 471-478.

Doyle, R. J. \& Koch, A. L. (1987). The functions of autolysins in the growth and division of Bacillus subtilis. Crit Rev Microbiol 15, 169-222.

Errington, J. \& Vogt, C. H. (1990). Isolation and characterization of mutations in the gene encoding an endogenous Bacillus subtilis $\beta$ galactosidase and its regulator. J Bacteriol 172, 488-490.

Fan, D. P. \& Beckman, M. M. (1972). New centrifugation technique for isolating enzymes from large cell wall structures: isolation and characterization of two Bacillus subtilis autolysins. J Bacteriol 109, $1258-1265$.

Fan, D. P. \& Beckman, M. M. (1973). Micrococcus lysodeikticus bacterial walls as a substrate specific for autolytic glycosidase of Bacillus subtilis. J Bacteriol 114, 804-813.

Fein, J. E. (1979). Possible involvement of bacterial autolysin enzymes in flagella morphogenesis. J Bacteriol 137, 933-946.

Fein, J. E. \& Rogers, H. J. (1976). Autolytic enzyme deficient mutants of Bacillus subtilis 168. J Bacteriol 127, 1427-1442.

Foster, S. J. (1991). Cloning, expression, sequence analysis and biochemical characterization of autolytic amidase of Bacillus subtilis $168 \operatorname{trpC2}$ J Gen Microbiol 137, 1987-1998.

Foster, S.J. (1992). Molecular analysis of three major wallassociated proteins of Bacillus subtilis 168: evidence for processing of the product of a gene encoding a $258 \mathrm{kDa}$ precursor two-domain ligand-binding protein. Mol Microbiol 8, 299-310.

Foster, S. J. \& Johnstone, K. (1988). Germination-specific cortexlytic enzyme is activated during triggering of Bacillus megaterium KM spore germination. Mol Microbiol 2, 727-733.

Hase, S. \& Matsushima, Y. (1977). The structure of the branching point between acidic polysaccharide and peptidoglycan in Micrococcus luteus cell wall. J Biochem 81, 1181-1186.

Hauser, P. M., Crabb, W. D., Fiora, M. G., Scoffone, F. \& Galizzi, A. (1991). Genetic analysis of the flaA locus of Bacillus subtilis. J Bacteriol 173, 3580-3583.

Helmann, J. D. (1991). Alternative sigma factors and the regulation of flagella gene expression. Mol Microbiol 5, 2875-2882.

Helmann, J. D., Màrquez, L. M. \& Chamberlin, M. J. (1988). Cloning, sequencing, and distuption of the Bacillus subtilis $\sigma^{28}$ gene. $J$ Bacteriol 170, 1568-1574.

Herbold, D. R. \& Glaser, L. (1975). Bacillus subtilis N-acetylmuramic acid L-alanine amidase. $J$ Biol Chem 250, 1676-1682.

Holtje, J.-V. \& Tuomanen, E. I. (1991). The murein hydrolases of Escherichia coli: properties, functions and impact on the course of infections in vivo. J Gen Microbiol 137, 441-454. 
Kariyama, R. \& Shockman, G. D. (1992). Extracellular and cellular distribution of muramidase-2 and muramidase-1 of Entercoccus birae. J Bacteriol 174, 3226-3241.

Karl, H. S. \& Kandler, O. (1972). Peptidoglycan types of bacterial cell walls and their taxonomic implications. Bacterial Rev 36, 407-477.

Kuroda, A. \& Sekiguchi, J. (1990). Cloning, sequencing and genetic mapping of a Bacillus subtilis cell wall hydrolase gene. J Gen Microbiol 136, 2209-2216.

Kuroda, A. \& Sekiguchi, J. (1991). Molecular cloning and sequencing of a major Bacillus subtilis autolysin gene. J Bacteriol 173, 7304-7312.

Kuroda, A. \& Sekiguchi, J. (1992). Characterization of the Bacillus subtilis $\mathrm{CwbA}$ protein which stimulates cell wall lytic amidases. FEMS Microbiol Lett 95, 109-114.

Kuroda, A. \& Sekiguchi, J. (1993). High-level transcription of the major Bacillus subtilis autolysin operon depends on expression of the sigma $\mathrm{D}$ gene and is affected by a $\sin ($ flaD) mutation. J Bacteriol 175 , 795-801.

Kuroda, A., Imazeki, M. \& Sekiguchi, J. (1991). Purification and characterization of a cell wall hydrolase encoded by the $\mathrm{cwl} A$ gene of Bacillus subtilis. FEMS Microbiol Lett 81, 9-14.

Kuroda, A., Rashid, M. H. \& Sekiguchi, J. (1992a). Molecular cloning and sequencing of the upstream region of the major Bacillus subtilis autolysin gene: a modifier protein exhibiting sequence homology to the major autolysin and spoIID product. $J$ Gen Microbiol 138, 1067-1076.

Kuroda, A., Sugimoto, Y., Funahashi, T. \& Sekiguchi, J. (1992b). Genetic structure, isolation and characterization of a Bacillus licheniformis cell wall hydrolase. Mol \& Gen Genet 234, 129-137.

Kuroda, A., Asami, Y. \& Sekiguchi, J. (1993). Molecular cloning of a sporulation-specific cell wall hydrolase gene of Bacillus subtilis. $J$ Bacteriol 175, 6260-6268.

Laemmli, U. K. (1970). Cleavage of structural proteins during the assembly of the head of bacteriophage T4. Nature 227, 680-685.

Lazarevic, V., Margot, P., Soldo, B. \& Karamata, D. (1992). Sequencing and analysis of the Bacillus subtilis lyt $\mathrm{R} A B C$ divergon: a regulatory unit encompassing the structural genes of the $N$ acetylmuramoyl-L-alanine amidase and its modifier. $J$ Gen Microbiol 138, 1949-1961.

Leclerc, D. \& Asselin, A. (1989). Detection of bacterial cell wall hydrolases after denaturing polyacrylamide gel electrophoresis. Can J Microbiol 35, 749-753.

Longchamp, P. F., Mauël, C. \& Karamata, D. (1994). Lytic enzymes associated with defective prophages of Bacillus subtilis: sequencing and characterization of the region comprising the $N$-acetylmuramoyl-L-alanine amidase gene of prophage PBSX. Microbiology 140, 1855-1867.

Margolis, P. S., Driks, A. \& Losick, R. (1993). Sporulation gene spoIIB from Bacillus subtilis. J Bacteriol 175, 528-540.

Margot, P. \& Karamata, D. (1992). Identification of the structural genes for $N$-acetylmuramoyl-L-alanine amidase and its modifier in Bacillus subtilis 168: inactivation of these genes by insertional mutagenesis has no effect on growth or cell separation. Mol \& Gen Genet 232, 359-366.

Margot, P., Mauël, C. \& Karamata, D. (1994). The gene of the $N$ acetylglucosaminidase, a Bacillus subtilis cell wall hydrolase not involved in vegetative cell autolysis. Mol Microbiol 12, 535-545.

Màrquez, L. M., Helmann, J. D., Ferrari, E., Parker, H. M., Ordal, G. W. \& Chamberlin, M. J. (1990). Studies of $\sigma^{\mathrm{D}}$-dependent functions in Bacillus subtilis. J Bacteriol 172, 3435-3443.
Maukl, C., Young, M. \& Karamata, D. (1991). Genes concerned with synthesis of poly(glycerol phosphate), the essential teichoic acid in Bacillus subtilis 168, are organized in two divergent transcription units. J Gen Microbiol 137, 929-941.

Miles, J. S. \& Guest, J.R. (1984). Nucleotide sequence and transcriptional start point of the phosphomannose isomerase gene ( $\operatorname{man} A$ ) of Escherichia coli. Gene 32, 41-48.

Miller, J. H. (1972). Experiments in Molecular Genetics. Cold Spring Harbor, NY: Cold Spring Harbor Laboratory.

Mirel, D. B. \& Chamberlin, M. J. (1989). The Bacillus subtilis flagellin gene ( $h a g$ ) is transcribed by the $\sigma^{28}$ form of RNA polymerase. J Bacteriol 171, 3095-3101.

Mirel, D. B., Lauer, P. \& Chamberlin, M. J. (1994). Identification of flagellar synthesis regulatory and structural genes in a $\sigma^{\mathrm{D}}$-dependent operon of Bacillus subtilis. J Bacteriol 176, 4492-4500.

Nagarajan, V. (1993). Protein secretion. In Bacillus subtilis and Other Gram-Positive Bacteria, pp. 713-726. Edited by A. L. Sonenshein, J. A. Hoch \& R. Losick. Washington, DC: American Society for Microbiology.

Nasir-ud-Din, Lhermitte, M., Lamblin, G. \& Jeanloz, R. W. (1985). The phosphate diester linkage of the peptidoglycan polysaccharide moieties of Micrococcus lysodeikticus cell wall. J Biol Chem 260, 9981-9987.

Oda, Y., Nakayama, R., Kuroda, A. \& Sekiguchi, J. (1993). Molecular cloning, sequence analysis, and characterization of a new cell wall hydrolase, CwlL, of Bacillus licheniformis. Mol \& Gen Genet 241, 380-388.

Oshida, T., Sugai, M., Komatsuzawa, H., Hong, Y.-M., Suginaka, H. \& Tomasz, A. (1995). A Staphylococcus aureus autolysin that has an $N$-acetylmuramoyl-L-alanine amidase domain and an endo- $\beta-N$ acetylglucosaminidase domain: cloning, sequence analysis, and characterization. Proc Natl Acad Sci USA 92, 285-289.

Pooley, H. M. \& Karamata, D. (1984). Genetic analysis of autolysindeficient and flagellaless mutants of Bacillus subtilis. J Bacteriol 160, 1123-1129.

Potvin, C., Leclerc, D., Tremblay, G., Asselin, A. \& Bellemare, G. (1988). Cloning, sequencing and expression of a Bacillus bacteriolytic enzyme in Escherichia coli. Mol \& Gen Genet 214, 241-248.

Rashid, M. H. (1993). Purification and cloning of the autolytic glucosaminidase from Bacillus subtilis. MSc thesis, Shinshu University, Japan.

Rashid, M. H., Kuroda, A. \& Sekiguchi, J. (1993). Bacillus subtilis mutant deficient in the major autolytic amidase and glucosaminidase is impaired in motility. FEMS Microbiol Lett 112, 135-140.

Robbins, P. W., Trimble, R. B., Wirth, D. F., Hering, C., Maley, F., Maley, G. F., Das, R., Gibson, B. W., Royal, N. \& Biemann, K. (1984). Primary structure of the Streptomyces enzyme endo- $\beta-N$ acetylglucosaminidase H. J Biol Chem 259, 7577-7583.

Rogers, H. J., Perkins, H. R. \& Ward, J. B. (1980). Microbial Cell Walls and Membranes. London: Chapman \& Hall.

Rogers, H. J., Taylor, C., Rayter, S. \& Ward, J. B. (1984). Purification and properties of autolytic endo- $\beta-N$-acetylglucosaminidase and the $N$-acetylmuramyl-L-alanine amidase from Bacillus subtilis strain 168. J Gen Microbiol 130, 2395-2402.

Rosario, M. M. L., Fredrick, K. L., Ordal, G. W. \& Helmann, J. D. (1994). Chemotaxis in Bacillus subtilis requires either of two functionally redundant CheW homologs. J Bacteriol 176, 2736-2739.

Sambrook, J., Fritsch, E. F. \& Maniatis, T. (1989). Molecular Cloning: a Laboratory Manual, 2nd edn. Cold Spring Harbor, NY: Cold Spring Harbor Laboratory. 
Sanz, J. M., Diaz, E. \& Garcia, J. L. (1992). Studies on the structure and function of the $N$-terminal domain of the pneumococcal murein hydrolases. Mol Microbiol 6, 921-931.

Schaeffer, P., Millet, J. \& Aubert, J. P. (1965). Catabolite repression of bacterial sporulation. Proc Natl Acad Sci USA 54, 704-711.

Schreier, H. J. \& Sonenshein, A. L. (1986). Altered regulation of the $g \ln A$ gene in glutamine synthetase mutants of Bacillus subtilis. $J$ Bacteriol 167, 35-43.

Sekiguchi, J., Ezaki, B., Kodama, K. \& Akamatsu, T. (1988). Molecular cloning of a gene affecting the autolysin level and flagellation in Bacillus subtilis. J Gen Microbiol 134, 1611-1621.

Shimotsu, H. \& Henner, D. J. (1986). Modulation in Bacillus subtilis levansucrase gene expression by sucrose, and regulation of the steady-state mRNA level by sacU and sacQ genes. J Bacteriol 168 , 380-388.

Shockman, G. D. \& Holtje, J.-V. (1994). Microbial peptidoglycan (murein) hydrolases. In Bacterial Cell Wall, pp. 131-166. Edited by J.-M. Ghuysen \& R. Hakenbeck. Amsterdam: Elsevier Science Publishers.

Svarachorn, A., Shinmyo, A., Tsuchido, T. \& Takano, M. (1989).
Autolysis of Bacillus subtilis induced by monovalent cations. Appl Microbiol Biotechnol 30, 299-304.

Takegawa, K., Mikami, B., Iwahara, S., Morita, Y., Yamamoto, K. \& Tochikura, T. (1991). Complete amino acid sequence of endo- $\beta$ $N$-acetylglucosaminidase from Flavobacterium sp. Eur J Biochem 202 , 175-180.

Thompson, J. S. \& Shockman, G. D. (1968). A modification of the Park and Johnson reducing sugar determination suitable for the assaying of insoluble materials : its application to bacterial cell walls. Anal Biochem 22, 260-268.

Tokunaga, T., Rashid, M. H., Kuroda, A. \& Sekiguchi, J. (1994). Effect of $\operatorname{deg} S-\operatorname{deg} U$ mutations on the expression of sigD, encoding an alternative sigma factor, and autolysin operon of Bacillus subtilis. $J$ Bacteriol 176, 5177-5180.

Wang, X., Mani, N., Patte, P. A., Wilkinson, B. J. \& Jayaswal, R. K. (1992). Analysis of a peptidoglycan hydrolase gene from Staphylococcus aureus NCTC 8325. J Bacteriol 174, 6303-6306.

Received 26 January 1995; revised 6 April 1995; accepted 11 May 1995. 